San Jose State University

SJSU ScholarWorks

Master's Theses

Master's Theses and Graduate Research

Summer 2014

\title{
Having Fun about Jesus:" Children's Constructions of Their Relationship to Church
}

Henry James Zonio

San Jose State University

Follow this and additional works at: https://scholarworks.sjsu.edu/etd_theses

\section{Recommended Citation}

Zonio, Henry James, "Having Fun about Jesus:" Children's Constructions of Their Relationship to Church" (2014). Master's Theses. 4489.

DOI: https://doi.org/10.31979/etd.9gju-g7an

https://scholarworks.sjsu.edu/etd_theses/4489

This Thesis is brought to you for free and open access by the Master's Theses and Graduate Research at SJSU ScholarWorks. It has been accepted for inclusion in Master's Theses by an authorized administrator of SJSU ScholarWorks. For more information, please contact scholarworks@sjsu.edu. 


\title{
A Thesis
}

Presented to

The Faculty of the Department of Sociology and Interdisciplinary Social Sciences San José State University

\author{
In Partial Fulfillment \\ of the Requirements for the Degree \\ Master of Arts
}

by

Henry J. Zonio

August 2014 
(C) 2014

Henry J. Zonio

ALL RIGHTS RESERVED 
The Designated Thesis Committee Approved the Thesis Titled

"HAVING FUN ABOUT JESUS:"

CHILDREN'S CONSTRUCTIONS OF THEIR RELATIONSHIP TO CHURCH

by

Henry J. Zonio

APPROVED FOR THE DEPARTMENT OF SOCIOLOGY AND

INTERDISCIPLINARY SOCIAL SCIENCES

SAN JOSÉ STATE UNIVERSITY

August 2014

Dr. Susan Murray Department of Sociology and Interdisciplinary Social Sciences

Dr. Amy Leisenring Department of Sociology and Interdisciplinary Social Sciences

Dr. Todd Ormsbee American Studies Program 


\title{
ABSTRACT \\ "HAVING FUN ABOUT JESUS:" CHILDREN'S CONSTRUCTIONS OF THEIR RELATIONSHIP TO CHURCH
}

\author{
by Henry J. Zonio
}

Children are not clay tablets upon which adults can etch predetermined futures. Rather, children are active agents who repeatedly interact with various social fields. Religion, one of those fields, is a major social institution that influences one's religious beliefs as well as one's secular behavior. Studying children's views on religion and how they relate to their religious communities makes explicit the ways children actively participate in their own religious socialization. Consequently, this study is an in-depth examination of children's participation in their religious communities at two evangelical Protestant churches in Northern California utilizing a multiple methods qualitative approach including participant observation field methods, focus group interviews of children, and content analysis of church documents. Consistent with current understandings in the sociology of childhood, our findings indicate that children separate themselves from those of adults by creating their own "kid congregations" that are distinctly separate from the adults. Our findings further indicate that, while children and adults see the church as a place to learn and have fun, children construct the relationship between fun and learning differently than do adults. Moreover, this research addresses a gap in the sociological literature regarding how children talk about their relationships to their church communities; it has implications for how one interprets and approaches current and future studies investigating how children relate to their religious communities. 


\section{ACKNOWLEDGEMENTS}

When I began working on this thesis I was ignorant of the time and effort that people, other than myself, would have to contribute in order for me to complete it. I would like to, first, thank the children who participated in the focus group interviews for this study. They entrusted me with their thoughts and beliefs about what it means to go to church, and I learned so much from them. My hope is that I have adequately represented their voices in this thesis. I would also like to thank the families and churches in this study for trusting me to enter into and study their religious communities.

Thank you to Dr. Amy Leisenring in the Sociology and Interdisciplinary Sciences Department as well as Dr. Todd Ormsbee in the American Studies Program for being a part of my thesis committee, reading my thesis and offering guidance and encouragement throughout this thesis process. Also, thank you to Delmy Figueroa and Karin DeSimone in the Sociology Department office for making sure I was filling out the correct forms and getting them in on time to graduate on time.

My deepest regards and appreciation go to Dr. Susan Murray for, not only being my thesis committee chair, but for reading countless iterations of my proposals and this thesis. I am in debt to her mentorship and encouragement.

Thanks most of all to Erin Zonio and our four children. They put up with my grumpiness over the course of these three years of grad school. They also listened politely as I shared with them all that I was learning. I could not have done this without their love and support. 


\section{TABLE OF CONTENTS}

List of Figures................................................................................................ vii

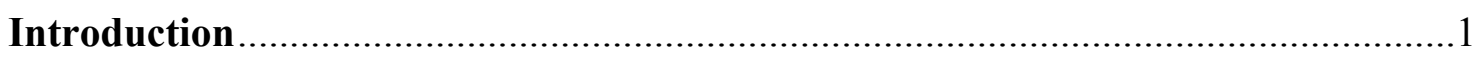

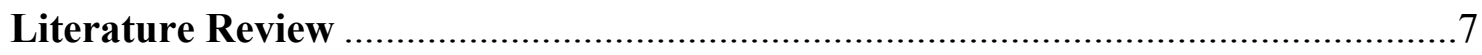

Sociological Perspectives on Religion..........................................................

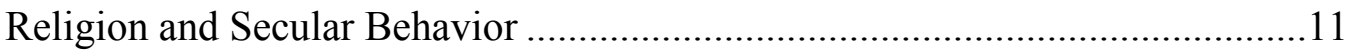

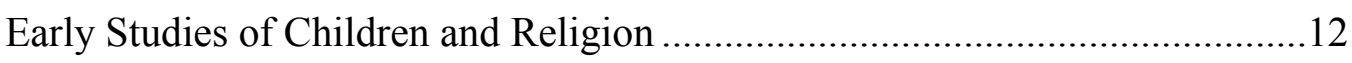

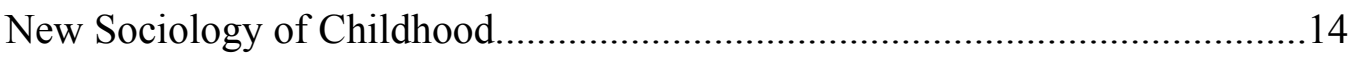

Contemporary Sociological Child Religious Studies .................................. 17

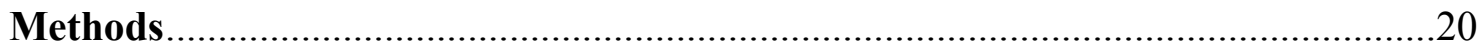

Conducting Research With Children .........................................................21

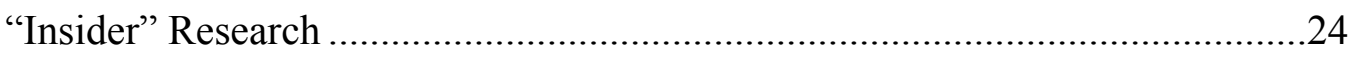

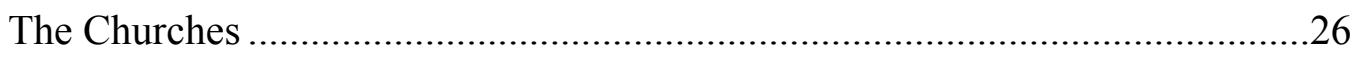

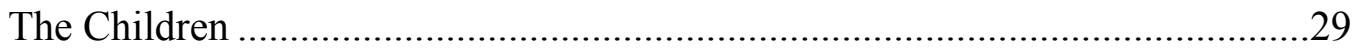

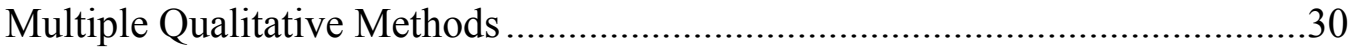

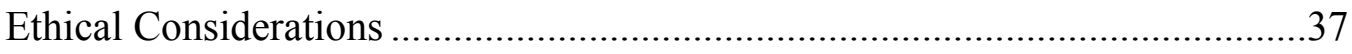

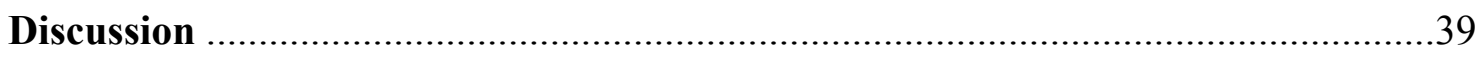

"Let the Children Come": Constructing Church as a Place Where Children

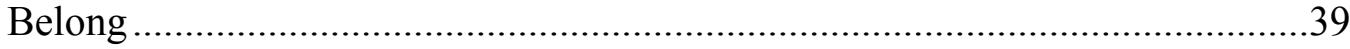

"Is That a Mom and Dad Church?" Children's Constructions of Separate

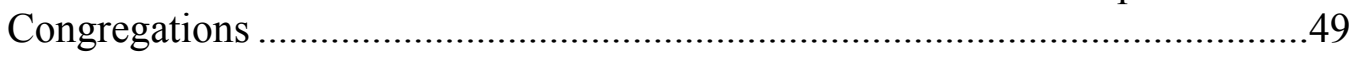

"Having Fun With Jesus": Constructing Church as a Place of Fun and

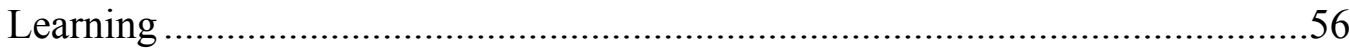

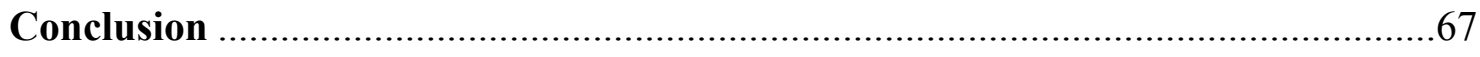

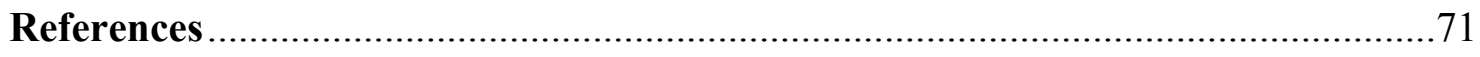

Appendix A: IRB Approval Letter .......................................................... 77

Appendix B: Informed Consent Letter for Parents....................................... 78

Appendix C: Informed Consent Letter for Children .......................................8 


\section{LIST OF FIGURES}

Figure 1. Brittany's drawing of a church building ...............................................50

Figure 2. Kirk's drawing of a pillow fight at The Chapel ........................................62

Figure 3. Victor's drawing of his mom picking him up from Sunday school..............62

Figure 4. Brett's drawing of a train and "party car" ............................................63

Figure 5. Carly's drawing of the Bible ................................................................64

Figure 6. Landry's drawing of a small group room with tables and chairs .................64 


\section{Introduction}

A few years ago, one of the parents at a church where I served as the director of children's religious education approached me. She had been observing our weekend programming for elementary school-aged children and noticed that her son was more interested in playing with his friend next to him than the lesson being taught at the front of the room. When she confronted him about this behavior he replied, "But Henry says we're supposed to have fun. It's one of the rules."

Technically, he was right. One of the rules, or "expectations," was: "Expect to learn something and have fun doing it." Up to that point, I assumed the meaning of "fun" was self-evident. "Having fun" meant the lessons and activities were to be enjoyable as opposed to boring. I had been completely unaware of the dissonance between my definition of "fun" and this child's understanding of what it meant to "have fun." Over the months that followed, I turned a critical lens on my taken-for-granted assumptions regarding how children learn and how they relate to the church. I pulled apart the curricula we used; I scrutinized the conversations my colleagues and I had about best practices in children's ministry; and I re-examined the many books, articles, and blog posts I had read or authored. Amongst all of those resources on the religious education of children, there was a scarcity of instances where children were consulted about their thoughts and views about attending church. I came to the startling realization that underlying my "child-targeted" approaches to relating with children in a church context was an adult-centric construction of how children connect with the church (Ridgely, 2012). It was this revelation that led me to turn my sociological lens towards an 
exploration of the ways children construct their relationships with the churches they attend.

As I began my research, I first had to address the saliency of a sociological study of the intersection between children and religion. In his chapter entitled "The Methodological Position of Symbolic Interactionism,” Blumer (1969) stated, “...human beings act towards things on the basis of the meanings that the things have for them" ( $\mathrm{p}$. 2). Furthermore, Blumer continued, “...symbolic interactionism sees meanings as social products, as creations that are formed in and through the defining activities of people as they interact” (p. 5). For many people, religious institutions are key sites for social interaction (Lenski, 1961; White, 1968). Sociological studies have shown that religious beliefs in the United States are linked to how one votes in an election (Manza \& Brook, 1997), one's political affiliation (DiMaggio, Evans, \& Bryson, 1996; Lenski, 1961; Wald, Owen, \& Hill, 1988), as well as one's views on popular social issues such as race relations, gender inequality, crime, women's rights, and gay rights (Gallagher, 2004; Hoffman \& Bartowski, 2008; Hunter, 1991; McConkey, 2001; Sherkat, 2000; Thomas \& Olson, 2012). White's (1968) analysis of religious influence stated that religion is a group phenomenon whereby community members interact with each other to shape normative expectations for behavior. White went on to argue that church members enforce group norms through interactions with each other (p. 25). Bearing in mind that $46 \%$ of those in the United States attend religious services at least once a month (General Social Survey, 2010), religion has a significant impact on individuals' secular behavior. 
One way to better understand how religion affects secular behavior is to examine the ways in which religious norms are reinforced and how children are socialized into those norms (White, 1968). According the 2004 U.S. Census Bureau Survey of Income and Program Participation (SIPP), 68\% of children six to eleven years old attended some sort of religious service, social event, or education program at least once a month. An examination of the literature revealed two dominant explanations for children's religious socialization: children's social learning by being drawn early into congregational life (Dudley, 1999) and "transmission" or "inheritance" of religious values by way of parental and familial influences (Gunnoe \& Moore, 2002; Hoge, Petrillo, \& Smith, 1982; Meyers, 1996). These perspectives on religious socialization, however, focused on children as passive receptors of religious norms rather than as active agents who participate in their socialization.

A search for child-centered perspectives on children's participation in religion uncovered a dearth of scholarship focusing on the voices of children as the basis for understanding how children construct their relationships with the churches they attend. Much of the research relied on the accounts of adolescents above the age of 13 or secondary accounts from adults (Beste, 2011). Several quantitative studies, for example, identified dominant indicators of adolescents' church attendance behaviors (Hoge \& Petrillo, 1978), their attitudes towards church and religion (Smith, Denton, Faris, \& Regnerus, 2002; Smith \& Lundquist, 2005), as well as how adolescents defined their religious identity (Lopez, Huynh, \& Fuligni, 2011). While these studies give sociologists a lens into the transition of religious beliefs and practices from adolescence to adulthood 
(Smith \& Lundquist, 2005), children's voices as experts of their experiences are silent. Even when children's views are solicited in religious research (Gunnoe \& Moore, 2002; Harms, 1944; Holifield, 2007), children are approached from the standpoint of who they will become as adult religious adherents. In her research with children exposed to domestic violence, Mullender (2002) attributed the lack of children's voices in sociological research to a belief that children are unreliable witnesses of their own experiences. Likewise, when it comes to child religious studies, Boyatzis (2011) and Beste (2011) separately noted that most research is based on a cognitive understanding of faith formation ${ }^{1}$ thus downplaying young children's abilities to discuss their religious views and experiences.

Over the past 30 years, social research has shown that children are more than mere bodies who passively undergo socialization into adulthood (Mannion \& I'anson, 2004; Thomas, 2007). Children have agency. They are constantly interpreting everything around them, reproducing those understandings with one another, and simultaneously shaping their social worlds along with the social worlds of adults (Corsaro, 2005). This collaborative act of social construction is called interpretive reproduction (Corsaro, 2003, 2005). Consequently, there is a growing body of social science literature articulating what it means to engage children as more than objects of study, but as key informants in research (Beste, 2011; Thomas, 2007). Examples of such research include: Corsaro's (2003) ethnography of preschoolers' peer group formation, Thorne's (1993) explication of how elementary aged children socially construct gender in

\footnotetext{
${ }^{1}$ See James Fowler's book, Stages of Faith (1981), for an in depth discussion of cognitive stages of faith expression.
} 
their interactions with each other, Mullender's (2002) exploration of how children exposed to domestic violence talk about their experiences, de Castro's (2012) study of children's views of their participation in Brazilian schools, and Blanchet-Cohen and Rainbow's (2006) child-centered analysis of children's participation in the International Conference on the Environment held in 2002 in Victoria, British Columbia, Canada.

As a result of this paradigm shift in the sociological study of children, which Corsaro (2005) termed the "New Sociology of Children," religious studies featuring children as key informants have modestly increased (Bales, 2005; Beste, 2011; Boyatzis, 2011; Dillen, 2007; Ridgely, 2011, 2012). Dillen (2007), for example, examined how children and adults can co-create religious knowledge and understanding in the context of family religious rituals. Another study, using a mixture of qualitative and quasiquantitative analysis, interviewed children on their understandings, feelings, and views about the Sacrament of Reconciliation in the Catholic Church (Beste, 2011). Similarly, using children as expert consultants of their experiences, Bales (2005) revealed that children interpret and appropriate the significance of religious rituals independent of parents and religious educators. These and similar studies challenge conventional psychological development approaches that interpret children's religious experiences through rigidly defined Piagetian cognitive stages (Fowler, 1981). Instead, these studies opt for a more interpretive model, recognizing that children are social agents with their own religious understandings (Beste, 2011; Boyatzis, 2011; Dillen, 2007).

Children are not simply "beings upon whom adult desires can be etched to ensure a particular kind of future" (Ridgely, 2012, p. 484). Rather, children actively construct 
their views and beliefs as they progress through childhood repeatedly interacting with various social fields (Corsaro, 2005). Religion, one of those fields, is a major social institution that influences one's religious beliefs as well as one's secular behavior (DiMaggio, Evans, \& Bryson, 1996; Manza \& Brook, 1997; Wald, Owen, \& Hill, 1988; White, 1968). Studying children's views on religion and how they relate to their religious communities makes explicit the ways in which children actively participate in their own religious socialization. Consequently, my study is an in-depth examination of children's participation in their religious communities.

In the chapters that follow, I begin by reviewing the literature regarding how sociological researchers have addressed the influence religion has on secular behavior, religious socialization, child-centered sociological research, and the intersection of child studies and the sociology of religion. Second, I provide a detailed discussion of my methodology, including ethical considerations concerning research with children. I end with an analysis and discussion addressing the following research questions:

- How do children construct their relationship with the churches they attend?

- What are some of the assumptions amongst church leaders and within church documents about how children relate to the churches they attend?

- How do children's accounts of their relationship to their churches compare to the kind of relationship church leaders want with child adherents? 


\section{Literature Review}

This thesis is a qualitative exploration of children's relationships to their religious communities. My research and subsequent analysis are part of a larger theoretical conversation involving sociological perspectives on religion, the influence of religious beliefs and values on one's secular behavior, and perspectives on religious socialization. Consequently, this chapter is a review of the sociological literature beginning with a discussion of how Marx, Durkheim and, Weber theorized about religion. I will then explore how sociological research has covered religion's influence on Americans' secular behavior. Finally, this chapter will end with an examination of what the sociological literature says regarding religious socialization, child-centered sociological research, and the intersection of child studies and the sociology of religion.

\section{Sociological Perspectives on Religion}

From the beginnings of the discipline of sociology, religion has been recognized as a formidable social institution. Marx described religion as a way for the oppressed classes to escape the reality of their exploitation, referring to religion as the "opium of the people" in the introduction to his Critique of Hegel's Philosophy of Right (1843/1970).

Durkheim, on the other hand, viewed religion as a social fact contributing to social cohesion. A key function of religion, according to Durkheim (1912/1915), is the delineation between aspects of society that are sacred (set apart for special or supernatural purposes) and profane. Once certain facets of a society have been deemed sacred, specific rituals and ceremonies are established as a way of signifying the elevated status of those sacred items and beliefs. Because sacred items and values differ from one 
group to the next, one's religious practices become an indicator of that person's membership in a particular social group. Additionally, religious practices reproduce and reinforce a society's shared values and beliefs. Indeed, both Marx and Durkheim viewed religion as a major social institution offering insights into how societies are structured and stratified.

While Marx and Durkheim focused on the function of religion in society as a result of social group membership, Weber sought to explicate the substantive aspects of religion. In other words, Weber was interested in defining religion within the context of the culture and history of social groups. Weber argued that societal ideals in a given geographical and historical location shape religious expression, which in turn can influence the actions of people. Moreover, rather than religion serving a universal social function or arising from a particular economic system, Weber viewed religion as a possible force of change in society. This was illustrated in Weber's attribution of the rise of capitalism to Protestant soteriology and asceticism in The Protestant Ethic and the Spirit of Capitalism (1930/2012). Noticing that Protestants seemed to be more industrialized and wealthier than their Catholic counterparts, Weber posited that the conditions for capitalism have always existed, and a significant reason for the rise of capitalism in the West stems from ideals within Protestantism (more specifically Calvinism) that lead to social actions which support capitalism. From a Weberian perspective, religion is a dynamic social institution that develops rationally from the ideals of a certain society and, in turn, has the ability to influence social action. In order to better understand religion's influence on other aspects of society, it is important to 
examine how members of religious groups are socialized into religious ideals, beliefs, values, and norms.

One might argue, though, that as society became more modern, societal ideals shifted towards replacing an epistemology based in religion with one based in scientific empiricism. Religion, therefore, is no longer needed as a means to explain the unexplainable, neither are societal values tied to religious ideals. This perceived decline in religion's influence in society is called secularization (Greeley, 1972; Sherkat \& Ellison, 1999). Casanova (2003) pointed out that this growing secularization of society should have marked the decline of religion. It would follow, then, that there is limited salience in contemporary sociological studies of religion. Current statistics tell a different story. Rather than showing a rapid decline in religious participation, statistics show that just under half of adults in the United States attend religious services at least once a month (General Social Survey, 2010). Furthermore, two thirds of children between six and eleven years of age attend some sort of religious service, social event, or educational program at least once a month (U.S. Census Bureau Survey of Income and Program Participation, 2004).

Contrasting the view that secularization marks a steady decline of religion, Wald (1992) stated, "Religion has certainly been touched and influenced by the modern world, but it is more accurate to speak of secularization as adjustment and adaptation than to employ the image of decline and fall” (pg. 14). Rather than secularization and religion existing at opposite ends of the theoretical spectrum, some sociological scholars argue that the institute of religion continues to exert influence over secular aspects of society 
(Hunter, 1991; Lenski, 1961; Wald, 1992). In an effort to explain religion's continued resilience as a significant social institution, sociological scholars have turned to economic models (Stark \& Bainbridge, 1987/1996) and denominationalism (Greeley, 1972; Wuthnow, 1976, 1985).

One of the theories explaining religion's influence in society is rational choice theory. Rational choice theory utilizes economic markets as a model for how individuals make decisions about religion. Rational choice theory assumes that people are agents free of any social influences, weighing the cost and benefits of religious belief or nonbelief, and choosing religious practices that benefit them the most (Stark \& Bainbridge, 1987/1996). On the other side of the theoretical spectrum, Sherkat and Ellison (1999) stated that religious choices are better understood by analyzing the social relationships influencing decisions. Using religious denominationalism (Greeley, 1997) as a framework, Wuthnow (1985) attributed religion's resiliency as a social institution to its ability to adjust to changes in society by way of religious renewal movements. In Wuthnow's words,

Denominational pluralism merely heightens the importance of [reform] movements, as members can easily switch religious preferences if their own denomination does not offer a sufficient menu of digestible entrées. Thus, the religious marketplace generates not only a single charismatic, feminist, or peace movement, but proliferates distinct denominational brands of each (Wuthnow, 1985, pg. 115). 
Rather than declining in influence, religion remains a formidable social institution that shapes the actions and behaviors of adherents in secular as well as sacred contexts. In the next section, I will explore interactional theories that describe how one's religious beliefs and values influences secular behavior.

\section{Religion and Secular Behavior}

Building upon the work of Marx, Durkheim, and Weber, social scholars shifted from theorizing on the nature of religion to examining how religious beliefs and values affected one's secular behavior. Leege (1993) stated, "Religion is not only an affinity. It is something that people act out in public and private ways" (p. 3). In other words, secular behavior stems from one's religious beliefs. For example, Sherkat (2000) demonstrated in his research that gendered discourse within fundamental Christianity surrounding housewifery as a "career" influenced women adherents of fundamentalism to postpone working outside of the home until her children had grown. In another study, Kellstedt (1993) suggested that religious beliefs were better predictors of political affiliation than socioeconomic status, age, or race.

According to White (1968), one theoretical explanation for the influence religion has on secular behavior focuses on individualistic attempts to reconcile one's theology with attitudes and behaviors in other areas of life. This explanation is akin to Weber's perspective that social action rationally arises out of ideological beliefs. White went on to point out, though, that such individualistic explanations of religious influence overlook deviant cases where empirical observations do not correlate with theological ideals. For example, in spite of Sherkat's (2000) findings regarding fundamentalist Christian women 
choosing a "career" as a homemaker, Carter and Corra (2005) analyzed General Social Survey (GSS) data over a 27 year period and found that views of women have become more liberal and egalitarian amongst fundamentalists. Drawing from Lenski’s (1961) theory that religion is a group phenomenon, White argued for an interactional model of religious influence where religious norms are reproduced and reinforced within the context of local church communities at the interactional level. In the words of White (1968), "Voluntary associations of individuals bound by strong affectivities and regular social interaction, churches constitute genuine communities that are well-suited to the transmission and maintenance of group norms" (p. 532). Put simply, the voluntary and intimate nature of local church communities are prime social locations for individuals to be socialized into the religious norms and beliefs of particular communities.

White (1968) stated that children are primary recipients of socialization within local church communities. It follows, then, that an examination of children's participation in their church communities may offer further insights into how one's secular behavior is influenced by religious beliefs and values. In the following section, I examine how early sociological studies of religion theorized the socialization of children.

\section{Early Studies of Children and Religion}

As scholars in the sociology of religion sought explanations for how religious institutions transmitted norms and values, a few studies pointed to early socialization into religious norms, values and beliefs (Lenski, 1960; Hunter, 1991). Harms (1944) analyzed children's drawings of their religious thoughts and experiences and articulated children's progressive understanding of religious concepts. Later, Fowler (1981) expounded upon 
Harms' findings articulating distinct and progressive stages of faith formation. Following a Piagetian-inspired model of cognitive development, Fowler described faith formation as a linear set of stages beginning at birth when children associate experiences of their environment with feelings of safety or mistrust towards the divine. Within the context of Fowler's stages, children do not develop their religious identities until 12 years of age. Later studies by Dudley (1999) and Smith and Lindquist (2005) suggested that children are socialized into their religious beliefs through parental example and early religious instruction. These and other early studies (Hoge \& Petrillo, 1978; Smith et al., 2002) on children and religion, while providing insight into the religious lives of children, relied on accounts of adults and adolescents or compared children's experiences with those of adults. Early studies of children in religion failed to interpret children's accounts of their religious experiences from a child-centered perspective. Lenski (1961) reinforced this bias towards leaving children's voices out of the literature on children in religions stating, "All intelligent human action presupposes assumptions about the nature of the forces which ultimately shape the nature and destiny of man. Only small children and persons of subnormal intelligence are non-religious in our sense of the term" (p. 299). In other words, early social research on children in religions assumed that children were incapable of understanding, let alone expertly testifying about, their religious experiences. In the final sections of this chapter, I examine contemporary theories of children as independent social agents and their influence on contemporary studies of children in religion. 


\section{New Sociology of Childhood}

Before 1980, very little research focused on the experience of childhood or focused on children in sociology (Shanahan, 2007). Leading up to that point in history, scholars described children as passive agents socialized into adulthood (Mannion \& I'anson, 2004; Thomas, 2007). Since then, the sociology of children and childhood has grown (Jans, 2004; Shanahan, 2007; Thomas, 2007). Children are now considered active agents who interpret culture and reproduce their understanding of culture through their interactions with each other as well as through their interactions with adults (Corsaro, 2003; Corsaro, 2005; Corsaro \& Eder, 1990). This is what Corsaro called "interpretive reproduction" (Corsaro, 2003; Corsaro, 2005). Corsaro (2003) conducted an ethnographic study of preschoolers and how they formed peer groups. One of Corsaro's key findings was that children, rather than simply appropriating aspects of the adult world into their everyday interactions with each other, strive for independence from adults and cooperate to share that independence with each other. Similarly, Thorne (1993) noted in her study of how elementary children construct gender, that children maintained covert worlds with their own symbols and interactions outside of the purview of their teachers. Each of those studies suggested that children have agency from a young age with the capability to independently engage in their social worlds. If children have agency, then it follows that when it comes to sociological research, the idea that children are not "mature enough" or developmentally able to meaningfully participate in research (BlanchetCohen \& Rainbow, 2006; de Castro, 2011) is false. This realization has led to a growing 
body of child-centered research highlighting children's participation in the communities and institutions they are a part of.

How the literature defines children's participation varies. Thomas (2007) offered the most systematic definition of children's participation in the literature: "Participation' can refer generally to taking part in an activity, or specifically to taking part in decisionmaking. It can also refer either to a process or to an outcome" (pg. 199). This definition suggests that children's participation can be seen as either active or passive. Participation is active in the sense that it can entail partnerships between adults and children to make something happen (Blanchet-Cohen \& Rainbow, 2006) or it can entail actively making decisions or participating in decision processes that have been traditionally been left to adults (Mannion \& I'anson, 2004). Participation can be more passive by being characterized as an expression and acknowledgement of children's opinions (de Castro, 2011). Whether children's participation is characterized as active or passive, the focus of children's participation is to move children from the realm of human "becomings" to respecting the agency of children and their contributions to society. "[Children] want to be respected as persons in their own right" (Graham \& Fitzgerald, 2010, pg. 346). Graham and Fitzgerald went on to outline that "respectful participation" means opportunities for participation should be genuine and focused on change; participation includes children having access to information; children want to participate in the decision-making process; and children see participation as "emerging within a mutual interdependence, recognition and respect for children and their views" (pg. 347). 
Children's participation is not without its challenges (Blanchet-Cohen \& Rainbow, 2006; Mannion \& I'anson, 2004; Thomas, 2007). When efforts are made for children to participate, it becomes apparent relatively quickly that most adults do not implicitly know how to work with children (Blanchet-Cohen \& Rainbow, 2006; Mannion \& I'anson, 2004). While the purpose of children's participation is to recognize children having agency, their needs and resources differ from those of adults and accommodations need to be made in order for children's participation to be meaningful and respectful (Blanchet-Cohen \& Rainbow, 2006). Unfortunately, children have little social capital (Thomas, 2007), so their needs are marginalized or overlooked because the workload on adults needed to accommodate children increases (Blanchet-Cohen \& Rainbow, 2006). Related to this issue of accommodating children is the reality that children come with gatekeepers. Parents, guardians, teachers and other gatekeepers need to be accommodated, sometimes more so, in addition to the children (Blanchet-Cohen \& Rainbow, 2006; Cheney, 2011).

Another challenge in children's participation surrounds the concern of disappointing the children that are being worked with. This disappointment manifests itself when children's participation makes no real difference in the outcome of projects or situations they are involved in (Thomas, 2007). Additionally, children face disappointment when adults are not able to follow through with what is promised to children (Blanchet-Cohen \& Rainbow, 2006; Mannion \& I'anson, 2004). One of the consequences of these challenges is that adults choose to act "in the best interests" of children to minimize the challenges. Unfortunately, the motivation for this kind of action 
is more based in the belief that children are not "mature enough" or developmentally able to meaningfully participate (Blanchet-Cohen \& Rainbow, 2006; de Castro, 2011).

In light of the challenges outlined above, one has to ask if the whole exercise is worth it? What is gained by making the effort for children to engage in meaningful participation? Why should adults bother with including children in decision processes that could very well be completed more efficiently and less costly without them? Shanahan (2007) stated, "An understanding of childhood as a fundamental category of sociological analysis reconceives adulthood, intergenerational processes, age grading, and gender. Such an understanding would fundamentally revise the way we study foundational sociological concepts...” (p. 424). Similarly, de Castro (2011) added, “...to include children's perspectives will demand a reframing of institutional goals, formats and procedures so as to accommodate the interests of these newly engaged social actors..." (p. 265). In other words, meaningful children's participation and the understanding that comes from it can reshape how we approach the discipline of sociology, specifically in areas of inequality (Shanahan, 2007) and how adulthood and childhood are conceptualized (Graham \& Fitzgerald, 2010).

\section{Contemporary Sociological Child Religious Studies}

In light of these contributions of child-centered research, social researchers have begun to enlist children as key informants in research. Children have shifted from subjects of research to expert consultants of their religious experiences and understandings. As a result, researchers are able to study the mutual effects children and religious institutions have on each other rather than focusing on children as adult 
worshippers in the making. Unfortunately, a search of the sociological literature reveals a scarcity of child-centered studies of children in religion.

Dillen (2007) argued that children are co-creators with adults in the understanding of religious concepts. Rather than approaching religious education where adults unilaterally pass information down to children, Dillen contended for a more communicative approach. This approach allowed for children and adults to exchange and negotiate meanings of religious concepts leading to refined or even new understandings. Similarly, Beste (2011) focused on how children's interpretations of a particular church ritual revealed, "children are actively co-constructing meaning and reality as opposed to merely absorbing and internalizing the teachings of adults" (p. 346). Furthermore, Beste (2011) suggested that engaging children as religious and moral agents might positively effect religious adherence into adolescence and young adulthood. A final study using children as key informants of children's religious experiences, examined children's interpretations of the Catholic ritual of First Communion (Bales, 2005). Through participant observation of First Communion classes and interviews of children, parents and church leaders, Bales (2005) revealed that children interpret the role and significance of church rituals independently of how adults view similar rituals. Additionally, Bales (2005) argued that age is a distinct sociological factor that should be considered (in addition to race, gender, and socioeconomic status) in sociological studies of religion.

While the above research brings to light young children's ability to substantively reflect on their religious beliefs, rituals, and experiences, there is a lack of literature exploring how children construct their relationships to their religious communities. 
While Bales (2005) suggested from her research that children do not feel like they are a part of the adult church community, she had no data or analysis examining children's construction of this felt separation or the implications this apparent sense of separation has on the study of children in religions. My thesis research addresses this gap in the literature by utilizing child-centered qualitative research methods to explore how children relate to their churches. I examine assumptions made by church leaders and church documents about the nature of children's participation in church. I then compare this habitus with children's actual experiences in their church communities. In the next chapter, I will explicate the methodology used in this research. 


\section{Method}

Blumer (1969) stated that one of the objectives of symbolic interactionism is "lifting the veils that obscure and hide what is going on [in an area of group life]" (p. 39). In order to "lift the veil" on the religious socialization of children, it is important to explore how children construct their relationships with the churches they attend as compared to how church leaders relate to children. The methodology for this research draws on Blumer's contention that one's methodology must be grounded in the qualitative exploration of the actions, interactions and experiences of people within their respective worlds. Therefore, I use a multiple methods qualitative approach including participant observation field methods, focus group interviews, and content analysis of church documents to examine the social world of children's religious education at two evangelical Protestant churches in Northern California.

The sections that follow start with a discussion of the special considerations surrounding research with children. Following this discussion, I will address the benefits and challenges of coming to this research as an insider within the world of religious education of children. Then, I describe the churches involved in this study as well as the child informants who shared their views and thoughts about church. Third, I describe a multiple methods approach utilizing content analysis, participant observation and focus group interviews along with an explication of the analysis of the data I gathered. Lastly, I speak to the ethical considerations that were a part of my research. 


\section{Conducting Research With Children}

Thorne (1999) stated, “Children’s experiences should be taken just as seriously, or lightly, as those of adults" (p. 6). Thorne's statement seems to be a mantra and an underlying principle guiding the methodological decisions described in the literature on child-centered research. In the same way, this study employs a methodology that focuses on research with children rather than research on children (Waksler, 1991). In other words, this study approaches children as informants and expert consultants of their experiences rather than as subjects observed from afar. Three key issues must be addressed when developing child-centered methodologies for research: the power differential between adults and children (Bales, 2005; Corsaro, 2003; Thorne, 1999); the recognition that children's understandings are different, not less, than adult's understandings (Waksler, 1991); and the unique challenges facing adults establishing rapport with children (Bales, 2005; Beste, 2007; Corsaro, 2003; Darbyshire, MacDougal, \& Schiller, 2005; Thorne, 1999). The deeper ethical issues regarding informed consent and confidentiality specific to research with children are addressed at the close of this chapter.

Mitigating the power differential between adults and children. In the introduction to Childhood Matters: Social Theory, Practice and Politics, Qvortrup (1994) argued that the lack of power children have stems from a prevailing belief that children are adults-in-the-making, or human becomings, rather than human beings. As a result of this view, adults marginalize children in society much in the same way other privileged groups have subordinated minority populations. In her research with minority 
communities, Zinn (1979) noted that research with minority groups must mitigate the power between researchers and participants in order to reduce the potential of exploiting those participating in research. While Zinn was speaking to research with racial minorities, the same principles apply when designing research with children.

One of the ways I addressed the power differential between the children I consulted for this thesis project and myself was by approaching them as experts of their experiences. Rather than presenting myself as a powerful adult, I drew from the suggestions of Corsaro (2003), Thorne (1999), and Bales (2005) and approached the children as an "atypical adult." An atypical adult is one who puts oneself in the position of learning from children, knowing less than the children do about the subject being discussed. I did this with the child informants interviewed by introducing myself as a student who was in school just like them and asked them to teach me about what they thought about church. Additionally, I let the children know that I would be using what they shared with me regarding their views about church to teach other adults what kids think about church (Darbyshire, et al., 2005; Ridgely, 2012).

Another way I attempted to lessen the difference in power between the children and myself was through the use of focus group interviews. A search of literature detailing social research utilizing focus groups with children revealed that children are more comfortable voicing their thoughts and feelings about various subject matter in a group setting rather than one-to-one (Corsaro, 2005; Darbyshire, et al., 2005; Ridgely, 2011; Peek \& Fothergill, 2009). Similarly, in a previous study I conducted using both focus groups and one-on-one interviews with children discussing their thoughts on video 
games, the children in focus groups more readily participated than those in one-on-one interviews (Zonio, 2013). In addition to children feeling more comfortable, focus groups place informants as experts regarding the topics of discussion (Reinharz, 1992; Ridgely, 2011).

Children understand differently, not less. Related to the issue of decreasing the imbalance of power between adults and children is the importance of recognizing children's understanding as different, not less, than an adult's understanding (Waksler, 1991). In order to accomplish this, I took the role of a listener, many times allowing children to control the direction of our conversations even if those directions seemed silly or unrelated to what we were discussing. For example, one of the children, while explaining a picture he drew of church, told a fantastical tale about traveling through secret tunnels in the church and hunting cattle. Instead of writing off his story as a foray into silliness and fantasy play and ignoring it in my analysis, it helped me see how children actively and creatively shape their constructions of church and not simply parroting what their parents and teachers tell them about church. However, had I not established a rapport with the children I interviewed, they would have been reluctant to share stories like the one above.

Establishing rapport with children. In his book, The Spiritual Life of Children, Coles (1990) recounts his efforts at establishing enough trust with children for them to be able to share their unfiltered thoughts on spirituality and religion. Similarly, Thorne (1999), Corsaro (2003), and Bales (2005) convey the time it took for each of them to be accepted by the children who informed their respective ethnographies. One of the 
common themes in literature on qualitative field methods is the importance of establishing rapport and the time it takes to develop rapport (Bales, 2005; Beste, 2007; Coles, 1990; Corsaro, 2003; Peek \& Fothergill, 2009; Ridgely, 2011; Thorne, 1993). While these researchers highlighted the lengthy time necessary to build rapport with research participants, Finch (1984) contended that it is possible to quickly establish rapport in a semi-structured interview setting that is informal and conversational. Similarly, Darbyshire et al. (2005) argued that rapport with children in a focus group interview can be quickly facilitated by maintaining an informal and familiar atmosphere as well as having a moderator who is comfortable working with children and is flexible. Since I have worked with children in religious settings for 20 years and am comfortable interacting with children, I was able to draw from Finch (1984) and Darbyshire et al. (2005) and quickly establish rapport with the child informants in my research. I conducted focus group interviews at the churches the children attended providing an informal atmosphere for the interviews. In order to keep from exploiting the rapport I had built with the child informants I had interviewed, I approached the interviews and my analysis as a way for children to have a voice in their churches as well as in future studies

of religion. Having worked to mitigate the effects of my "outsider" status in the world of children, it was necessary to consider both the benefits and challenges of my "insider" status with regards to church membership.

\section{"Insider" Research}

Over the course of 20 years, I worked in religious education as a volunteer and as part of the pastoral staff at various churches. I am fluent in the culture and language that 
accompanies the religious education of children. As a result of my experiences working in child religious education, I come to this research as an insider when it comes to the standpoint of adults who work in the church. In her studies with minority communities, Zinn (1979) pointed out that conducting research as someone who is part of the social group facilitates easier access to that social group. My status as an insider in the world of religious education allowed me a similar advantage. Once I had identified the churches that would be a part of my research by way of purposive sampling, I was able to use my connections with gatekeepers and my familiarity with church risk management policies to gain access to those churches as sites for conducting my research with greater ease than those who are outsiders.

In addition to its benefits, insider research has the potential of exploiting those being researched (Finch, 1984; Zinn, 1979), especially those from oppressed classes. However, in this case, the subjects of research I approached as an insider were churches, which would not be considered oppressed or minority groups. Regardless, the church communities in this study may benefit from the research by opening themselves up to examination in the hopes of better understanding how children relate to the churches they attend and how church leaders could better respond and incorporate children in to the "life" of the overall church. I will now turn to an explication of the churches and child informants participating in this study followed by a discussion of how I gathered and analyzed data. 


\section{The Churches}

My study utilized purposive sampling methods (Babbie, 2013; Silverman, 2010) to determine which cases would provide the most reliable and valid data for this project. "Purposive sampling allows us to choose a case because it illustrates some feature or process in which we are interested... [It] demands that we think critically about the parameters of the population we are studying and choose our sample case carefully on this basis" (Silverman, 2010, p. 141).

This research qualitatively explores how children construct their relationships with the churches they attend and compare those constructions with church leaders' attempts at relating with children. Blumer (1969) states, “[Symbolic interactionism’s] empirical world is the natural world of such group life and conduct. It lodges its problems in this natural world, conducts its studies in it, and derives its interpretations from such naturalistic studies” (p. 47). Drawing from Blumer's statement, I originally approached three evangelical Protestant churches located in Northern California. According to these churches' websites and literature, such as their worship bulletins and informational brochures, children are an important part of the churches. One church website states, “Children's Ministry exists to partner with parents to help children discover and follow Jesus for a lifetime" (First Christian Church ${ }^{1}$ website, 03/14/2014). The churches also conduct children's religious programming that meet parallel to the adult worship service in separate, age-graded teaching environments. In the end, only two of the churches I approached were able to grant me access and participate in the

\footnotetext{
1 The names of the churches in this study have been changed to maintain confidentiality of the participants in this study.
} 
study. I obtained letters from gatekeepers at each of the churches granting me access to approach families from those churches about children participating as child informants for this study. I submitted copies of those letters as part of an application for Institutional Review Board (IRB) approval to conduct this study, and I have retained those letters as part of my field notes.

First Christian Church is a 140-year-old, mainline Protestant church that identifies itself as evangelical (First Christian Church website, March 15, 2014) and is located in an affluent community. The church has an average weekly attendance of 2,300 people, of which 475 are children six months old to 10 years old (personal correspondence with the children's ministry director, March 14, 2014). First Christian Church has four worship services: one on Saturday evening and three on Sunday morning. There are children's programs that run concurrently with the adult worship services during the Saturday evening service and the two later services on Sunday morning. The children meet in agegraded classrooms in separate buildings from the main sanctuary where adults meet. The elementary school aged programming follows a "large group/small group" format (Miller \& Staal, 2004). Children (usually no more than 10) are assigned to age-graded "small groups" with a volunteer leader, or Sunday school teacher. When children first arrive at First Christian Church, they meet in their small groups. Soon after the church service begins, all the kindergarten through third grade small groups meet together in a larger room as a "large group." In this large group, the children sing songs and listen to a Bible story. After the large group time finishes, the children return to their small groups where leaders follow a curriculum to review the Bible lesson until the adult worship service 
ends and parents pick up their children. Over the course of three months, I conducted qualitative field research as a participant observer at First Christian Church employed in the children's ministry department. Additionally, I conducted focus group interviews of children in kindergarten through third grade at First Christian Church. I will discuss each of these methods in greater detail later on in this chapter.

The other church in this study is Christian Community Church. Christian Community Church is a twenty year old, nondenominational evangelical Protestant church (Christian Community Church website, March 15, 2014) located in a middle class area. The church has an average weekly attendance of 5,000 people, of which 850 are children six months old to ten years old (personal correspondence with the children's ministry director, March 14, 2014). Similar to First Christian Church, Christian Community Church has four worship services: one on Saturday evening and three on Sunday morning. There are children's programs that run concurrently with the adult worship services during all four of the church services. The children meet in age-graded classrooms in a wing of the building separate from the main sanctuary where adults meet. The elementary school aged programming follows a "large group/small group" format similar to First Christian Church. In addition to a content analysis of the Christian Community Church's website and its policies and procedures regarding children, I conducted focus group interviews with children from kindergarten through third grade. I will discuss each of these methods in greater detail later on in this chapter. Now, I turn my attention to the child informants who are a part of this study. 


\section{The Children}

As part of exploratory research Blumer (1969) stated, "One should sedulously seek participants in the sphere of life who are acute observers and who are well informed" (p. 41). With this in mind, I decided to elicit the voices of children as expert consultants of their experiences at church in order to explore how children construct their relationships with the churches they attend. Drawing from Corsaro's (2005) orb web model of child development, I focused on interviewing children from a single peer group participating in the religious social field made up of kindergarten through third grade children. At both churches, this age grouping goes through the same curriculum and meets together during the "large group" time.

Utilizing theoretical sampling (Babbie, 2013; Silverman, 2010), I determined that children who would be considered "acute" and "well-informed" observers of their churches are children who attend church two or more times a month. Gatekeepers at each of the churches provided me with contact information for families that fit the above theoretical criteria. After receiving IRB approval (Appendix A), I contacted 26 families from First Christian Church and 10 families from Christian Community Church. I sent an email to the families introducing myself as a graduate student at San José State University, briefly describing my research exploring how children construct their relationships to church and asked if their children would be interested in sharing their thoughts and feelings about church with me along with a group of other kids from their church. In the end, five boys and two girls from First Christian Church and two boys and two girls from Christian Community Church participated in focus group interviews as 
child informants. All of the children stated that they attend church on a weekly basis unless they were on vacation or sick. Additionally, three of the children from First Christian Church and one child at Christian Community Church had a parent who was employed at the church. The children received no monetary compensation for their involvement in this project. However, the children were able to benefit from their participation with this project by contributing their voices to the conversation surrounding children and religion (Bales, 2005; Beste, 2011; Ridgely, 2011, 2012).

\section{Multiple Qualitative Methods}

"[E]xploratory inquiry is not pinned down to any particular set of techniques. Its guiding maxim is to use any ethically allowable procedure that offers a likely possibility of getting a clearer picture of what is going on in the area of social life" (Blumer, 1969, p. 41). Heeding Blumer's advice, I have utilized multiple qualitative methods to explore how children construct their relationships to their church communities and compare those constructions with how church leaders attempt to relate to children. Furthermore, Zinn (1979) argued that a multiple methods approach allays the influence a researcher may have on the field of research by providing various perspectives of empirical reality. Therefore, I utilized three sets of data, which will be discussed in further detail in the sections that follow.

I conducted field research as a participant-observer over the course of three months while employed at First Christian Church. During this period, I gathered data on how church leaders approach the religious socialization of children, as well as, how children conduct themselves within the empirical world of the church. I also carried out 
content analysis of policies and procedures from both churches as well as the religious education curriculum used by both churches to further explore how church leaders relate to children. Lastly, I conducted focus group interviews of children from both churches in this study to collect first-hand accounts of children's thoughts and feelings about church.

By combining my field observations of children at church with first-hand accounts from children in the focus group interviews and comparing those with an analysis of the churches' attempts to relate with children, my aim is to explore how children actively construct their relationships with the church that resist and reinforce how church leaders relate to children.

Qualitative field research. One set of data for this research comes out of my field research as a participant observer at one of the churches in this study. Whyte (1979) stated, "[A] participant observer is a researcher who participates in social activities with the subject of study over an extended period of time" (p. 56). Moreover, field research allows the researcher to study attitudes and behaviors within the empirical world being studied (Babbie, 2013). Consequently, I conducted three months of field research while employed at First Christian Church so as to position this study within the empirical world of religious socialization.

From the outset, I entered the field as an overt researcher (Whyte, 1979) informing my supervisor as well as co-workers that I was conducting research on the religious socialization of children. Additionally, I informed my supervisor and coworkers that the location of the church as well as the identities of everyone at the church 
would be confidential. Furthermore, as a result of my prior experiences in religious education, I was able to enter the field as a complete participant (Babbie, 2013, p. 299).

While at First Christian Church, I worked with the children's ministry staff to edit curriculum, recruit and train volunteers, plan events, set up for weekend children's programs, and teach in the elementary school-aged program environment. Participating in this way allowed me to observe interactions between the children's ministry staff and the ethos of the church leading to decisions on how the church community should relate with children. Furthermore, I was able to directly observe how church leaders and volunteers interacted with children. Additionally, I made note of interactions children had with each other, with the church environment, and with the leaders and volunteers who were part of the children's religious programming. Approaching this field research as an overt and involved participant allowed me insight into the social processes, assumptions, and interactions that guide how the church relates with children that I would not have otherwise observed had I approached the field as a detached observer (Whyte, 1979).

Drawing from Babbie (2013) and Silverman (2010), I recorded field notes that included empirical observations of the church as well as my interpretations of those observations. Throughout the days I worked in the office and during the weekend children's programming, I jotted down brief notes in a pocket-sized notebook I carried with me. At the end of each day I worked at the church, I wrote more detailed notes distinguishing between my empirical observations and my interpretations of what happened. As I will discuss later in this section, I combined my field notes with the data 
from focus group interviews with children, and with my analysis of church documents, to examine children's relationships with the church.

Focus groups. Another set of data for this research was obtained through the use of focus group interviews. Addressing the use of focus groups, Blumer (1969) stated, A small number of individuals, brought together as a discussion and resource group, is more valuable many times over than any representative sample. Such a group, discussing collectively their sphere of life and probing in to it as they meet one another's disagreements, will do more to lift the veils covering the sphere of life than any other device that I know of (p. 41).

In other words, by using focus group interviews, I was able to combine the advantages of in-depth interviews with observations of social interactions (Leech, 2002; Montell, 1999). Furthermore, Montell (1999) stated that, as part of a focus group, children more easily participate and collaboratively construct meaning around the interview questions. In addition to putting children at ease, focus group interviews place interviewees as experts of the topics discussed (Leech, 2002; Reinharz, 1992). This approach is consistent with Ridgely's (2011) proposal that children be viewed as experts of their religious experiences. In following with the suggestions from Peek and Fothergill (2009) and Morgan, Gibbs, Maxwell, and Britten (2002) regarding optimal numbers of focus groups and participants in each group, I had arranged to conduct two focus group interviews at each of the churches in this study with five children in each group. By keeping the group size to a maximum of five children, I would be able to maximize discussion while maintaining order and keeping within the allotted time set aside for the 
interview, which was one hour (Peek \& Fothergill, 2009). In the end, I conducted three focus group interviews. Two of the groups had four children in each, and one of the groups consisted of three children.

Gatekeepers at each of the churches in the study provided me names of children for the focus groups. These were the same gatekeepers who granted me access to the churches. Focus groups were made up of children who were between kindergarten and third grade and attended church an average of three times a week. Interviews were conducted at each of the churches in order to set the children at ease by providing an environment the children were already familiar with (Ridgely, 2011). I recorded the interviews using a digital voice recorder. Subsequent to conducting the focus groups, I transcribed the interviews yielding approximately 200 pages of text. Electronic copies of the recording and transcripts were saved on my computer as well as backed up on an external hard drive protecting them with a password.

Prior to contacting the children and their parents for the focus group interviews, I secured permission from each of the churches involved in the study to interview children at the churches. I also petitioned and received approval from the Institutional Review Board at San Jose State University to conduct interviews with the children in this study (Appendix A). Furthermore, I maintained confidentiality of the children's identities by using pseudonyms for the names of the children and the names of the churches throughout this thesis.

"Listening" to pictures. As part of the focus group interviews, the children were asked to "draw a picture of church" (Coles, 1990; Harms, 1944; Ridgely, 2011). 
Drawing allows children to artistically articulate what they may have trouble verbally articulating (Ridgely, 2011). Rather than decoding the pictures on my own, I followed Ridgely's (2011) suggestion and allowed the children to guide me in the interpretation of their pictures. I prompted this discussion saying, "Tell me about what you've drawn." This was done in an effort to mitigate bias on my part in the interpretation of the drawings. Throughout the focus group interview process, I took the position of learning from the children about their religious communities and their experiences with those communities as well as their experiences with religion (Ridgely, 2011; Waksler, 1991). Many times, other children in the focus group would reinforce and elaborate about each other's pictures.

Content analysis. In addition to field observations and focus group interviews, the final set of data used in this research arises from a content analysis of the websites, brochures, and policies and procedures regarding children from both of the churches in this study. Furthermore, in order to fill out categories emerging from analyzing field notes and focus group transcripts, I analyzed content from three months of religious curriculum used by both churches.

Babbie (2013) stated, "Content analysis is particularly well suited to the study of communications and to answering the classic question of communications research: 'Who says what, to who, why, how, and with what effect?'” (p. 331). Accordingly, I analyzed the content above for how children are addressed, assumptions made about children, as well as how leaders and Sunday school teachers are trained to relate with children. 
Data analysis. After gathering data from field observations at First Christian Church and from focus group interviews at both churches in this study, I used grounded theory methods as a means to allow codes and categories to arise from the data (Charmaz, 2006) thus mitigating my biases as a result of my prior involvement as an adult teaching child religious education and as a former child who grew up in church. I performed initial line-by-line coding (Charmaz, 2006) of the interview transcripts as well as my field notes, interview notes, and church documents followed by focused coding. Drawing from Charmaz (2006), I coded each line of the transcripts, field notes, and church documents noting assumptions of participants and texts and processes leading to making meanings of symbols in the empirical world of children in church. Throughout the coding process, I constantly compared emerging codes with previous and new data making note of differences and similarities across the data (Charmaz, 2006, p. 53). As similar codes emerged, I placed them into common categories. At this point, I began focused coding of the data.

"Focused coding requires decisions about which initial codes make the most analytic sense to categorize your data incisively and completely" (Charmaz, 2006, p. 59). Charmaz went on to state that these decisions are made by further comparing codes and data with other codes and data revealing categories that explicate recurring processes. As categories emerged, I composed thematic memos, building my analysis of the socially constructed worldview of the children and churches in this study from the ground up. During this stage of data analysis, I noticed that the religious education curriculum influenced how church leaders and volunteers constructed their relationships with 
children. Consequently, I conducted content analysis on three months of the curriculum used at both churches in this study. I paid special attention to content that filled out categories I had already identified regarding how curricular pressures influenced the church leaders' constructions of their relationship with children. I composed further memos incorporating the data gathered from content analysis of curriculum. Excerpts from my various memos were incorporated into the final analysis of this study.

\section{Ethical Considerations}

As I gathered and analyzed data for this thesis, I worked to conform to the ethical standards set forth by the American Sociological Association's (ASA) "Code of Ethics and Policies and Procedures of the ASA Committee on Professional Ethics" (1999), specifically Article 12.04, which addresses informed consent with children. In accordance with my university's procedures regarding the involvement of human participants in research, I obtained IRB approval from the university (Appendix A). Subsequent to receiving IRB approval, I sent emails to 27 families from the churches in this study introducing myself as a graduate student conducting thesis research exploring how children relate to churches they attend. As part of that initial contact, I included informed consent forms for parents (Appendix B) detailing the use of focus group interviews with the children as well as an explanation that participation in this research is voluntary on the part of both the parent and the child. Furthermore, I included informed consent forms for the children (Appendix C).

Corrigan (2003) argued that obtaining informed consent from subordinated participants could be problematic; some participants might not completely understand the 
scope of their consent to participate and choose to participate in research as a result of a sense of coercion or trust of those in positions of power rather than as a result of rational choice. In an effort to mitigate this power dynamic, I offered children multiple opportunities to clarify or withdraw their consent to participate in this research. Additionally, I used language in the children's consent forms as well as in the course of the focus group interviews that is common to children in kindergarten through third grade. Moreover, I asked parents to review the scope of this study with their children, stressing the importance of allowing their children to choose for themselves whether or not to participate in this study. The above considerations regarding obtaining consent from children not only conformed to ASA ethical guidelines, they served to recognize children's agency and autonomy (Ridgely, 2012). For example, a parent stated that he was "sure" his child would want to participate. Upon discussing the children's informed consent form with his child, the child decided not to participate in the focus group interviews. Both the parent and I affirmed this child's decision.

Along with informed consent, I had to address issues of confidentiality in my research. First, I assigned pseudonyms to the churches and the children who participated in this study. Second, I have not included any demographic or other identifying information that would reveal the identities of the churches or the children in this thesis. Finally, I have securely stored and saved original notes, transcripts, and recordings; I deleted or disposed of additional copies of notes, transcripts, and recordings. Throughout the entire research process, I was the only person with access to the original notes, transcripts, and recordings. 


\section{Discussion}

In this chapter I will first discuss how adult adherents and documents from the churches in this study construct church as a community children can belong to. I will then show how children construct their own "kid churches" that are distinctly separate from "adult churches." I will conclude this chapter by comparing how leaders and documents from the churches in this study construct the church as a place to have fun learning with how the children construct the church as a place of fun and learning.

\section{"Let the Children Come": Constructing Church as a Place Where Children Belong}

In the Bible, there is an account of Jesus' followers preventing children from "bothering" Jesus. In response to his followers' actions, Jesus says, "Let the children come to me" (Matthew 19:14; Mark 10:14; Luke 18:16, New Living Translation). When I worked in children's religious education I heard this story used many times as a description of the kind of relationship church communities should have with children; adult church members should openly welcome children as a part of the church community rather than treating them as peripheral or subordinate to the church community. In the course of analyzing the data from field notes and content analysis of church documents for this study, I found that the prominent discourse regarding the disposition of the churches towards children was that those churches are places where children are "welcome." For example, Christian Community Church's website states, 
We believe the EVERY child should have a place where...

They are known.

They are welcome.

They BELONG.

(accessed March 15, 2014).

The webpage goes on to stress the importance of relationships children have with each other and with significant adults at church as ways children can "belong" at church. Similarly, in my field observations at First Christian Church, a lot of time was spent making sure children were placed in a "small group" they would interact with and build relationships with on a weekly basis. Additionally, the children's ministry director at First Christian Church talked multiple times within the contexts of staff meetings, volunteer training and recruiting, as well as in email communications to volunteers, about the importance of helping children establish relationships with adult mentors who could support parents' efforts in teaching their children Christian values and beliefs. In light of the importance leaders and documents from the churches in this study placed on interpersonal relationships, I identify three relationship types the churches talked about, which I label intergenerational relationships, familiar relationships, and communal relationships. Following a discussion of the types of relationships, I consider the dialectical challenge curricular expectations have on church leaders' attempts to construct close relationships with child attendees.

Intergenerational relationships. In the course of conducting field observations at First Christian Church, I observed that a high value was placed on intergenerational relationships. Intergenerational relationships connect children with adults, especially 
adults from older generations, who could mentor those children. In their research exploring adolescents' continued adherence to church values and beliefs, Smith and Lundquist (2009) suggest that one factor influencing adherence is meaningful relationships one has with adults in the churches they attended as a young child. Leaders at both churches in my study cited Smith and Lundquist (2009) as well as similar research done by Powell and Clark (2011) as the impetus for prioritizing intergenerational relationships.

One example of this emphasis on intergenerational relationships occurred at the beginning of the school year a few days before First Christian Church performed what was called the "Kindergarten Blessing." For this blessing, the incoming kindergarteners were brought into the main sanctuary during the adult worship service where one of the pastors affirmed that children are part of the larger church community and prayed a blessing over the children. Subsequent to this event, each of the kindergarteners received a Bible with their names in them. A few days before the Kindergarten Blessing a group of senior citizen members of the church spontaneously showed up in the children's ministry office to help write the names of kindergartners in the Bibles that would be given to the children. One of the children's ministry staff stated, "It's great to have seniors labeling the Kindergarten Bibles. It connects them with the kids" (field notes, 09/25/2013). The children's ministry staff even took pictures of the seniors writing names in the Bibles. Furthermore, the children's ministry director sent out an email to the rest of the church staff with the subject, "It takes a whole church to help kids love Jesus." In the email, the children's ministry director wrote, "What a beautiful picture of a 
multi-generational church in action." What the seniors did was even highlighted in the adult worship services that weekend.

All through the above episode, what the seniors did was framed within the context of intergenerational relationships. The staff spoke of the seniors connecting with the kids through this act of service. Additionally, the children's ministry director furthered institutional discourse regarding intergenerational relationships by way of an email to the entire church staff. As a result, one of the lead pastors elevated the value of intergenerational relationships in the church by linking what the seniors did with additional discourse on the importance of adults building mentoring relationships with children.

Familiar relationships. In addition to intergenerational relationships, I found that the churches in my study also talked about the importance of children having familiar relationships within the church. By familiar relationships, I mean that leaders from the churches in this study placed a value on having a consistent person or "face" (field notes, 02/08/2014) children can build a relationship with. In the words of one of the leaders I interacted with at Christian Community Church, "We want every child to be known" (field notes, 01/05/2014). In other words, church leaders want to have relationships with children that are familiar.

During my time at First Christian Church, the ideal of familiar relationships was reinforced by volunteer recruitment calls for "regular weekly volunteers" emphasizing the importance of being a consistent "familiar face" children could look forward to seeing from week to week. Further, at a children's ministry volunteer training event that 
members from both churches in this study attended, one of the speakers stated, "Kids come back to church looking for a regular face" (field notes, 02/08/2014). This speaker went on to elevate the value of familiar church relationships by way of an example of how a child who had not spoken to anyone for six months after her father left the family, chose to open up and speak to a "familiar face" who happened to be one of the consistent children's ministry volunteers at the girl's church.

As shown in the above examples, leaders from the churches in this study assume that children will build meaningful relationships with the adults who are consistently involved in children's ministry. In turn, the churches believe that these familiar relationships will translate into children feeling like they are a part of the overall church community as evidenced by the conference speaker's statement above that children come to church as a result of a "regular face." Alongside the discourse about helping children form familiar relationships, leaders from the churches I studied expressed a desire to help children form communal relationships.

Communal relationships. Communal relationships are the close-knit relationships children have with their peers and a trusted adult leader within the context of a "small group" (Miller \& Staal, 2004). At the churches in this study, each small group consisted of at least one children's ministry volunteer and up to ten children from the same grade level in school. There were both gender specific and non-gender specific groups at both churches with groups becoming more gender specific the older the children in the groups were. According to the values listed by the children's ministry at First Christian Church, small groups exist to "provide a community for [children] to grow 
spiritually" (First Christian Church website, 03/14/2014). This value suggests that communal relationships are an ideal context for children's socialization into religious norms, values and beliefs.

Both First Christian Church and Christian Community Church placed a high priority on small groups. Children having a communal relationship with the church was so important that one of the most time consuming administrative tasks I observed at First Christian Church involved the creation and maintenance of small groups. Some of the major responsibilities of two of the full time children's ministry staff at First Christian Church, especially at the beginning of the school year, were recruiting and training of small group leaders and assigning children to consistent small groups. The only other responsibility that required more time than managing small groups was preparing weekly curriculum for the children's programs, which raises a major dialectical challenge to these ideal relationships the leaders and documents from the churches in my study attempted to construct with children.

Distanced Relationships. Although the prominent discourses amongst leaders and in documents from the churches in this study emphasized that church communities were places where children could have meaningful relationships with adult mentors and peers, I observed a scarcity of relationships that were intergenerational, familiar or communal. For example, when I asked the children in the focus groups to identify people they knew at church, only one of the children could name one of the other kids in his small group, while only one other child was able to name her small group leaders (focus group interview, 01/05/2014, 01/12,2014). Additionally, when I asked the children if 
they spent any time with anyone from church outside of church, none of the children indicated that they did so (focus group interviews, 01/05/2014, 01/12/2014). I only observed one example of interpersonal relationships occurring at the churches in this study. One of the small group leaders at First Christian Church consistently showed up to the children's ministry office to send birthday cards and notes to the children in her group. She had also intentionally connected with the parents of the children her group on a weekly basis to "check in" on the families (field notes from First Christian Church).

A search of the data for factors that might illuminate the discrepancy between the churches' ideology and church leaders' actual practices revealed two possible explanations. First, preparing for each week's lessons required a large amount of time and energy. Second, discourses in the churches from this study, by way of signage and leader interactions with parents and children, explicitly and implicitly communicated that children pose a threat to adults experiencing a distraction-free worship service.

Sunday keeps coming. Multiple times throughout my field notes from First Christian Church, I recorded a common jest amongst the children's ministry staff: "Sunday keeps coming." This phrase implied that the work going into the weekly preparation of curriculum and supplies left little time to do anything else. Additionally, small group leaders at First Christian Church regularly expressed concerns over the ability to complete all the curricular activities with their groups.

An examination of the curriculum used by both of the churches in this study indicated a priority on teaching biblical information, with relationships as a peripheral goal. Multiple pages of supplies and props required for the teaching and learning 
activities accompanied each week's curriculum. Weekly materials given to the small group leaders began with these instructions: "Focus the [children's] energy on today's Bible story in a Small Group setting with an engaging discussion question and an interactive opening activity" (Basic Truths ${ }^{1}$ church curriculum). A subsequent section of the curriculum weekly stated, "Make the connection of how today's Bible story applies to real life experiences through interactive activities and discussion questions" (Basic Truths church curriculum). These instructions for small group leaders focused on exploiting the use of "engaging discussion" and "interactive activities" to teach the weekly Bible story. After listening to a Bible story, singing songs and completing the learning activities, there was little time for small groups to become familiar with each other and feel connected as a community. A small group leader spontaneously told me one Sunday, "We [small group leaders] don't have enough time to do all the activities in the curriculum and connect with the kids" (field notes from First Christian Church). While small group leaders were encouraged to build interpersonal relationships with the children in their groups, they felt pressure to "do all the activities" each Sunday leaving little to no time for the children and leader to "get to know each other better" (field notes from First Christian Church). In addition to the external pressure negatively impacting church leaders' desire for children to foster meaningful relationships with each other and adult mentors by way of curricular demands, I found underlying internal negative discourses regarding children's impact on adults' worship experience at both churches in this study.

\footnotetext{
${ }^{1}$ The name of the curriculum has been changed to maintain confidentiality of the participants in this
} study. 
No children allowed. Further examination of the data from my field notes and content analysis of church documents for other factors adversely affecting how churches relate to children uncovered explicit and implicit discourses of children as threats to adults experiencing distraction-free worship services. While attending a large national children's ministry conference a few years ago, one of the keynote speakers, a lead pastor of a large church, spoke of how excited children were to come back to his church from week-to-week, even to the point of convincing parents who would rather sleep in to bring them to church on the weekends. This pastor listed what he believed were some key characteristics of a church that was welcoming to kids. One of his points was, "No children allowed in the sanctuary." He argued that children were a distraction in the "adult service," and "they'd have more fun in an environment tailored specifically for them." In my observations of the churches in this study, I found that each church communicated a similar message that children are distractions.

Christian Community Church, while not prohibiting children from being in the "main" sanctuary, had signs at the sanctuary doors stating, "Families with children, please use the children's ministry classrooms or the family chapel" (field notes, 01/05/2014). Using a more implicit tactic to direct children away from the adult sanctuary, I observed multiple instances of leaders at First Christian Church telling children that "big church is boring" and that children would have more fun participating in the children's programming (field notes from First Christian Church). While the approaches at each of the churches were slightly different, the discourses at each church 
actively communicated that the sanctuary is the adults' domain where children do not belong.

Analyzing data from the National Congregations Study, Wilcox, Chaves, and Fanz (2004) reveal that church discourses about the importance of ministry to families do not correlate with a significant increase in the number of family programs available at churches. Drawing from studies of organizational rhetoric and institutional practices (Powell \& DiMaggio, 1991; Scott et al., 1994), Wilcox et al. (2004) suggested that "religious discourse on the family operates more as a mark of religiocultural identity than as a guide to pastoral practice" (pg. 492). In other words, institutional pressures produce a chasm between churches' discourses on family and actual programs available for families. In a similar way, institutional pressures, by way of the religious education curricula, to teach Bible stories and religious beliefs, prevented church leaders in this study from intentionally providing space and opportunities for children to develop interpersonal relationships with each other and with adults.

Despite the challenges and contradictions accompanying the church's emphasis on children forming intergenerational, familiar, and communal relationships, the data from my field notes and content analysis of church documents suggest that church leaders believe these interpersonal relationships are the dominant ways in which children currently relate to the church. This strong belief was exemplified by a spontaneous conversation I had with a leader while I observed the children's programming at Christian Community Church. This leader was excited about Christian Community Church's recent emphasis on making sure every child was a consistent part of a small 
group stating a priori that children come to church because of their friends and the relationships they have with the people at church (field notes, 01/05/2014). However, drawing from the focus group conversations with children from First Christian Church and Christian Community Church, I found that the children saw themselves as a congregation distinctly separate from the adult congregation.

\section{“Is That a Mom and Dad Church?" Children's Constructions of Separate \\ Congregations}

One of the findings that emerged from analysis of the focus group interviews is that the children referred to two different churches - the "church" the children went to, which I call "kid church," and the "church" the adults went to, which I call "adult church"- when they talked about church. Furthermore, the data from focus group interviews revealed that children's connections with their churches were based on rituals the children shared as part of kid church rather than based on interpersonal connections with each other or adult leaders. Indeed, most of the children in this study preferred kid church to adult church. In this section, I will discuss the data showing how children construct kid church and adult church. I will then investigate how the children reproduce "kid church" through shared rituals. I will end this section by exploring why some children might choose to attend adult church instead of kid church.

"The other church". In my conversations with the children from First Christian Church and Christian Community Church, I found that they quickly identified a difference between what children and adults do at church. Many times the adult worship service was referred to as "The other church" or "Their [adults'] church." 
A defining example of this happened in the final group I interviewed at First Christian Church. I had asked the children to "draw a picture of church." Brittany ${ }^{2}$ (age 6) drew a multi-story building with people looking out of windows complete with a cross and a bell on top of the building (Figure 1).

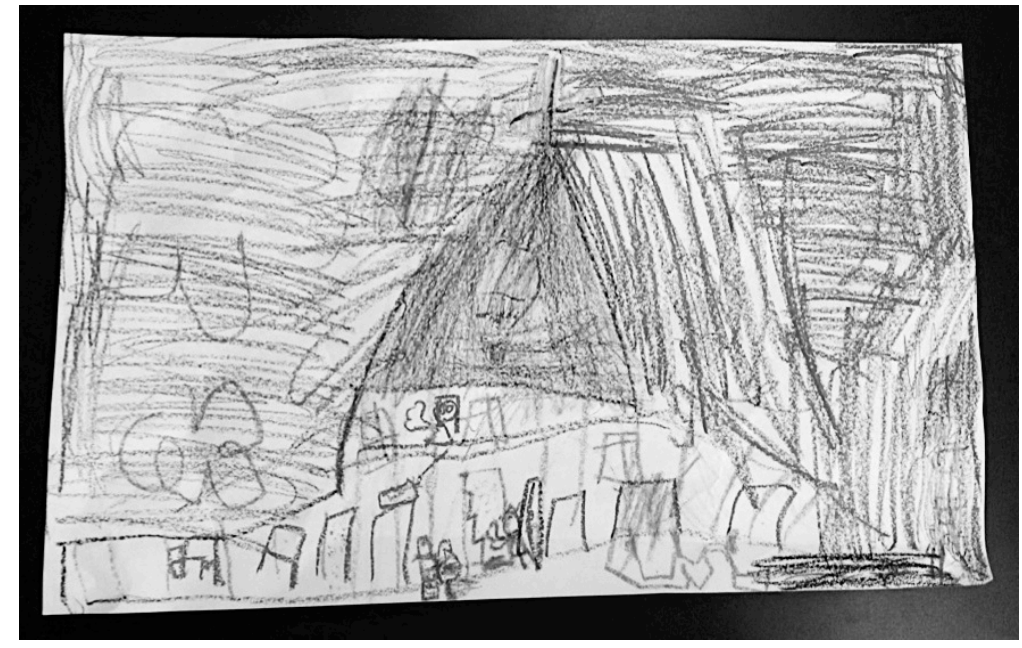

Figure 1. Brittany's drawing of a church building.

When I asked her to describe her picture to me, Landon (age 5), another one of the children in the group, chimed in, "Is that a mom and dad church?" When I asked Landon what a "mom and dad church" was, he simply pointed back to Brittany's picture and said, "That!" I was curious to learn the difference between a "mom and dad church" and how it differed from the "church" he went to. When I asked about it again, Leroy (age 9), the other child who was a part of this particular group stepped in saying, "Their sanctuary... They do more Bible study than us. We learn about... We learn about a story and they mostly, uh, learn about life, life happening." Brittany and Landon nodded their heads in agreement of Leroy's summation (focus group interview, 01/12/2014).

\footnotetext{
2 The children have been given pseudonyms to maintain confidentiality of the participants in this study.
} 
In that brief exchange, the children had socially engaged in reinforcing and revising each other's definitions of "mom and dad church." This is what Corsaro (2003) calls interpretive reproduction. While I had suspected that children felt disconnected from the overall church community, this finding that children constructed a kid church that was distinctly different from adult church surprised me. In essence, this finding suggests that children see the church they go to as made up of two separate congregations: kid church and adult church. For the balance of the time I spent with that group, I was sure to clarify what the children meant when they used the word, "church." Additionally, I adjusted my usage of the word, "church," specifying the difference between kid church and adult church.

Not only did I revise my usage of "church" with that particular focus group, I went over the transcripts from previous focus groups to see if the children in those groups also constructed two separate churches. With my newfound understanding of the dichotomous usage of the word "church," I began to see how the children in all of the focus groups had clearly delineated their experience of church as distinctly different from the adults' experience of church.

For example, in the first focus group from First Christian Church, I asked the children if they would still come to church if their parents didn't attend church. When I asked this question, I was still under the assumption that "church" meant the overall church community including adults and children. Kirk (age 7) clearly stated, "[The Chapel] is boring and for adults. I'd still go to [children's program] because you get to do fun stuff when you get there and you get to sing fun songs" (focus group interview, 
01/12/2014). At the time, I thought Kirk's delineation of "The Chapel" and the children's programming was a simple acknowledgement of multiple programs at a single church community. Looking at this interaction with my newfound understanding that children separated their church communities into two distinct congregations, I revised my understanding of Kirk's statement realizing that Kirk had constructed "The Chapel" as "adult church" and the children's program as "kid church."

Throughout the focus group interviews, the children created their own kid congregations that were distinctly separate from the adult congregations. This was a stark contrast to what leaders and documents from the churches in this study assumed about how kids related to the church. Rather than being integrated into the whole church, which includes children and adults, the children separated themselves. This division is consistent with findings by Corsaro (2003) and Thorne (1993), which show that children strive to create peer group cultures separate from adults. One of the ways the children reinforced and reproduced the distinct identity of kid church was through the use of shared rituals.

From routine to ritual. One of the first things I asked all of children in the focus groups to do was to tell me about their churches. All three of the groups began with a detailed schedule of what they did at church. While each of the schedules had minor differences, all of the children began by being checked in to their church's children's program by parents and receiving a nametag. Parents then escorted their children to the children's classrooms where children were free to engage in a variety of play activities. After a brief period of free play, the children joined other children from other classrooms 
in a larger room to sing, play a game, and hear a Bible story. At the conclusion of the Bible story, the children returned to their class rooms where they reviewed the Bible lesson with a "small group leader." Finally, the children were allowed to freely engage in play activities until their parents picked them up (focus group interviews, 01/05/2014, 01/12/2014).

At the time of the interviews, I interpreted these accounts from the children as mere recountings of the routines church leaders imposed upon them. Upon further analysis of the focus group interview transcripts, these seemingly mundane adult-centric routines took on a more significant ritualistic quality when viewed from the standpoint of the children. Thorne (1993) recounts a similar phenomenon amongst elementary aged school children whereby the children in her study utilized the exchange of everyday objects such as pencils, erasers, toy cars, and lip-gloss to signify social hierarchies and friendships. The children developed an "underground economy" (pg. 21) using what teachers and other adults saw as everyday objects as a means of exchanging and gaining social capital.

Drawing from Thorne's (1993) findings, an analysis of the children's "schedule of events" reveals that these routines take on sacred ritualistic qualities that strengthen the children's relationships with each other and their relationships with leaders at kid church. Take for example the following exchange amongst the children from Christian Community Church when I asked them to let me know what happens when they get to church. 
Becky (age 7): Well, we first have to come in and we have to check in. Um, and then...

Jason (age 7): We can wait for a little bit.

Darcy (age 9): You get nametags... And then your parents also get one, so that you can check out but not with the wrong person.

Becky: $\quad$ Yeah. You have to have...

Darcy: 'Cause you're with the right person

Becky: $\quad$ Your parents, like, have to have... uh...

Darcy: $\quad$ A tag.

Becky: $\quad$ A tag that has the same number as your tag.

Darcy: Yeah.

Jason: $\quad$ To get picked up...

Becky: $\quad$ So that they can take you home.

Jason: $\quad$ Yeah.

Becky: Uh huh

Darcy: Yeah

(focus group interview, 01/05/2014)

The children continued to detail how the nametags indicated the classrooms they are in as well as how one checks in by providing their "last four digits," which the children conferred about and confirmed mean the last four digits of their home phone number. Throughout the above conversation, the children excitedly engaged in a mutual exchange affirming each other's experience of the "check-in ritual." The children I interviewed from First Christian Church shared similar experiences of a "check-in ritual" with the exception of emphasizing "going upstairs" as part of their "check in ritual" instead of providing their "last four digits" (focus group interviews, 01/12/2014). Consistent with an interpretive reproduction framework (Corsaro, 1993), the children transformed a secular routine (computerized check-in), instituted by church leaders and 
used by parents as a way to keep children secure while at church, into a sacred ritual marking the children as belonging to kid church rather than adult church. The children transformed similar routines like transitioning between small group and large group times into rituals of belonging as well.

In The Sociology of Religious Belonging, Carrier (1965) stated that participation rituals develop a sense of communion and solidarity amongst religious practitioners. In other words, shared rituals create a sense of connection between those practicing those rituals. While the children interviewed in this study practiced common rituals working towards a shared narrative of what it means to go to church, their rituals differed from more historic rituals children have engaged in such as catechism or first communion. In her study of Catholic second graders' first experience the confessional, Beste (2011) showed that children felt a stronger connection with their churches (including the adults) after participating in the ritual. In contrast to the rituals practiced by the children in Beste's study, the rituals practiced by the children I interviewed emphasized and reinforced their separation from adult church. Consequently, all of the children I interviewed, except one, strongly stated their preference of attending kid church as opposed to adult church.

Choosing to go to adult church. One of the questions I asked the children in the focus groups was about their least favorite parts of church. Each of the kids identified parts of their churches that were boring. Leroy's response, though, surprised me: “...I'd rather go to the sanctuary than [kid] church because I kind of got the simple lessons at [kid] church, so I need kind of deeper... and... more..." (focus group interview, 
$01 / 12 / 2014)$. Up to this point in my analysis of the data, I had not encountered an explanation for Leroy's desire to sever his membership with kid church and join church with the adults. I returned to the categories and memos I'd accumulated from the focus group interviews as well as my field notes searching for an explanation to this

phenomenon. Reviewing the above data, I found that, in addition to children relating to the church as two separate "churches," children construct a relationship that intertwines the church as a place where they learn about God and a place where they have "fun." From this standpoint, Leroy's desire to attend church with the adults because he could learn more there begins to make sense. Leroy stated that he already "got the simple lessons" and was ready to learn "deeper" and "more." Kid church, for Leroy, was no longer a place he could relate to as a place where he was learning. Leroy related more to adult church as the place where he could learn more. In the next section, I explore how children construct church as both a place of learning and a place of "fun."

\section{"Having Fun About Jesus": Constructing Church as a Place of Fun and Learning}

The third major finding I encountered as I analyzed the data from the various methods used in this study, points to how leaders and documents from the churches in this study and the children both constructed church as a place of fun and learning. In this section, I highlight how leaders and documents from the churches in this study differ from the children in this study regarding how each group constructs the dynamic between learning and fun at church. First, I will explore how leaders from the churches in this study construct a relationship with children that incorporates "fun" as a pedagogical method to make learning more enjoyable for children. Second, I will explicate how 
children construct their relationship with their churches as both a place of learning and a place of fun. I conclude this section with an analysis of possible implications this relationship has on children's commitment to both kid church and adult church.

Church as a place to have fun learning. I found that when leaders from the churches I studied talked about fun and learning, fun was used as a pedagogical method to teach religious values and beliefs. This discourse was reinforced in children's ministry volunteer training materials and events. For example, at a regional children's ministry training event that members of both of the churches in my study attended, one of the leaders stated, "Kids don't come back [to church] if [learning the Bible] is not fun... If kids are not having fun learning the Bible with us, they won't want to learn the Bible on their own" (field notes, 02/08/2014). This leader went on to illustrate effective Bible storytelling methods by utilizing props, having volunteers join the storyteller as characters in the story, and recruiting the audience to provide sound effects. This leader predicated children's relationships with their church communities on learning experiences that are "fun." As I explored how leaders and documents from the churches in this study constructed the role of learning and fun in church, I discovered two values governing the interplay between learning and fun: (1) reproducing religious values and beliefs are the most important part of a lesson and (2) pedagogical methods are meant to make learning those values and beliefs palatable.

Prioritizing content. According to Durkheim (1912/1915), religious values and beliefs serve as a way of binding social groups together. Furthermore, Wuthnow (1999), stated that formal religious education, along with familial religious practices, contributes 
to what he called a "subculture of common understanding" amongst people of similar faith traditions (p. xxxi). In other words, the values and beliefs that are taught as part of religious education programs contribute to a person's identification with that religious community. It was no surprise, then, that the children's ministry staff at First Christian Church firmly grounded weekly learning experiences in codified religious beliefs prior to tailoring those experiences to be "fun" (field notes from First Christian Church). Consequently, the curriculum used by both of the churches in this study reinforced placing a priority on teaching religious beliefs and values. "Just under six thousand" churches across the United States use Basic Truths, the religious education curriculum utilized by both churches in this study (personal communication with Basic Truths staff, 03/12/2014). Regarding the purpose of the curriculum, the Basic Truths website stated:

On the whole, [Basic Truths] invites kids into the Story of God, to show them the character of God, all while helping them internalize the 3 Basic Truths. We also throw in some unforgettable illustrations, activities, and graphics to capture their attention and keep it relevant (accessed 03/14/2014).

In the above statement, the Basic Truths curriculum constructed church as a place to "show," or teach, children about God and help them "internalize," or learn, basic religious values and beliefs using some fun pedagogical elements to "capture [kids'] attention." This statement from the Basic Truths website reinforced and reproduced amongst church leaders an habitus that takes for granted the priority of content when it comes to the interplay between learning and fun. The above statement also communicated that "fun" is used to make learning more pleasant for children. 
Just a spoonful of sugar. In light of the high priority placed on teaching the right content, what place does "fun" have in how leaders and documents from the churches in this study construct church as a place for children to learn about God? In my time at First Christian Church, we created stage backdrops to "engage kids' imagination," we played games to "grab kids' attention," and we tweaked Bible story presentations to "make them more fun so the kids will pay attention" (field notes from First Christian Church). "Fun" was employed as a pedagogical device rather allowing kids to have fun for its own sake. In other words, "fun" was used in the same way Mary Poppins sang about using a "spoonful of sugar to help the medicine go down" in the 1964 Disney movie Mary Poppins. Consistent with top-down developmental (Fowler, 1981; Harms, 1944) and generational transmission (Gunnoe \& Moore, 2002; Hoge, Petrillo, \& Smith, 1982; Meyers, 1996) theories of children's religious socialization, children are seen as incapable of understanding abstract religious values and beliefs and must be "tricked" into learning religious content. Put more simply, the churches in this study, as well as the curriculum used by the churches, assumed that if learning is made fun, then children would not be able to tell the difference between "learning" and "fun." However, in the course of one of the focus group interviews, Leroy pointed out the ineffectiveness of constructing the church as a place where children can have fun learning about God: "You do [fun] activities and for some reason they try to hide the learning from it. [He chuckles.] But unfortunately they can't do that." The "bait and switch" tactics that use "fun" as a pedagogical method to socialize children into religious values, norms and beliefs did not so easily fool Leroy. As I reviewed the data from the focus group 
interviews, I found that rather than seeing church as a fun place to learn about God, the children in this study constructed church as a place where they learned about God as well as a place they could have fun.

Church as a place to learn and to have fun. Whereas leaders and documents from the church in this study constructed the church as a place where children have fun learning about God, the focus group interviews revealed that the children had a different understanding of "fun" and learning. One of the questions I asked the children in the focus groups was, "What's one thing you want people to know about church?" I was hoping to elicit responses that would illuminate how children articulate their relationship with the church to other people.

Me: What's one thing... you want people to know about church?

Darcy (age 9): It would be... about Jesus.

Peter (age 6): Yeah! It would be... to have fun!

Darcy: $\quad$ And God.

Me: $\quad$ To have fun? About Jesus?

Peter: Yeah!

Jason (age 7): Yeah, it's about Jesus.

Peter: Having fun about Jesus.

(focus group interview, 01/05/2014)

Leading up to this conversation, the children had described church as a place to learn about God or Jesus. Alongside those descriptions, the children had also talked about church as a place to have fun. In the above exchange, the children synthesized a relationship between the two descriptions. First, Darcy reinforced the church as a place to learn about God, followed by Peter contributing the other dominant depiction of 
church as a place to have fun. When I asked for clarification, Peter merged the two previously independent descriptions into, "Having fun about Jesus." In other words, the children constructed the church as a place to both learn and have fun. This is different from leaders and documents from the churches in this study constructing church as a place to have fun while learning. "Fun" and "learning" are two separate aspects of the relationship children have with the church, but both of those aspects are necessary for children to have a relationship with the church. Before examining the interconnectedness of fun and learning in children's relationship with the church, I will discuss how the children in this study constructed church as a place to have fun and a place to learn by way of the focus group data.

As I explored the connections children made between church being a place to learn and a place to have fun, I discovered a dissonance between how the church leaders and documents defined fun and how children talked about fun. Whereas, church discourses used "fun" as a pedagogical tool, a completely different picture of what the children described as "fun" became apparent as I talked with the children from First Christian Church and Christian Community Church.

Following Ridgely's (2011) suggestion about having children draw out their thoughts and answers to questions when conducting research with children, I asked the children I spoke with to "draw me a picture of church." I offered no further directions other than affirming children's thoughts about what it meant to draw a picture of church. As the children drew their pictures, I asked them to tell me about their pictures. Kirk's picture depicted a pillow fight with other children (Figure 2), which he assured me 
happened regularly after church at "The Chapel" venue of First Christian Church, because they are fun and are his favorite part of church.

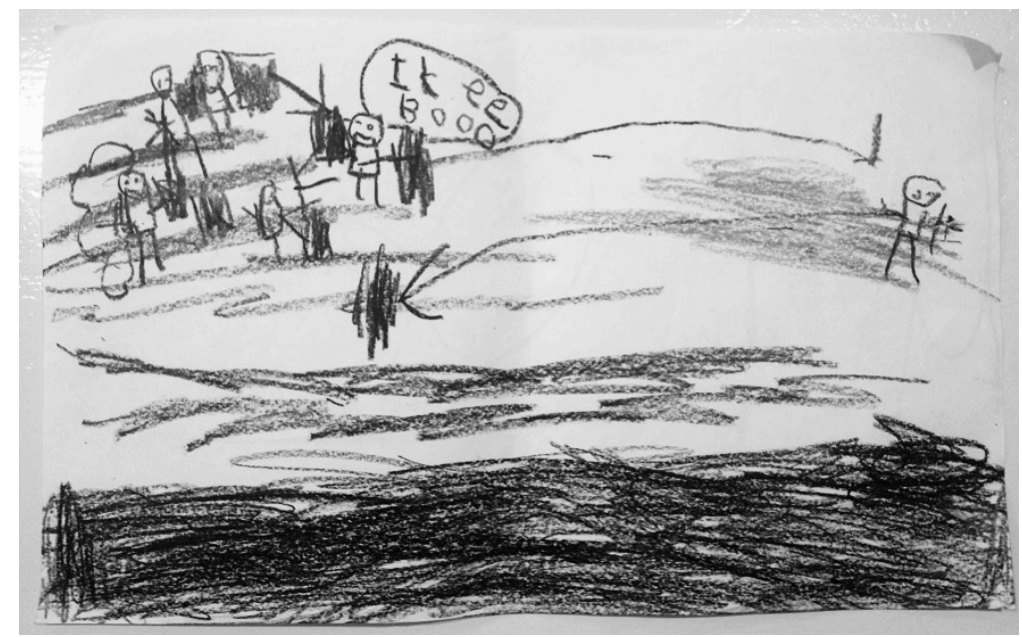

Figure 2. Kirk's drawing of a pillow fight at The Chapel.

Victor also drew about his favorite part of church, which was when his mom picks him up so he can show her the fun things he made in his class (Figure 3).

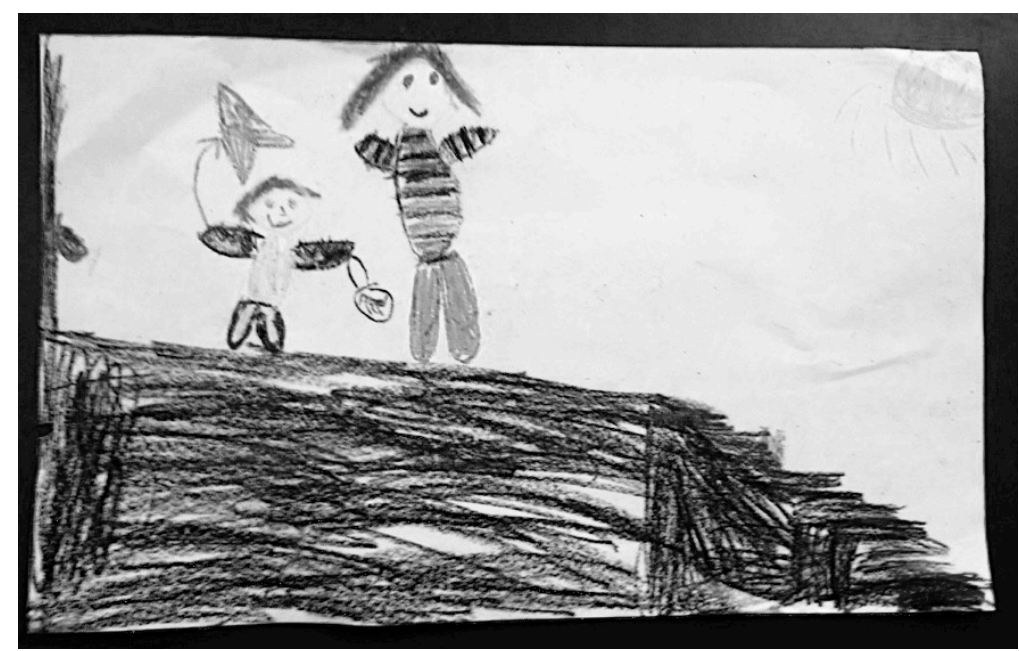

Figure 3. Victor's drawing of his mom picking him up from Sunday school.

Another picture, drawn by Brett (age 5), was of a train complete with a "party car" and confetti coming out of the train's smokestack (Figure 4). 


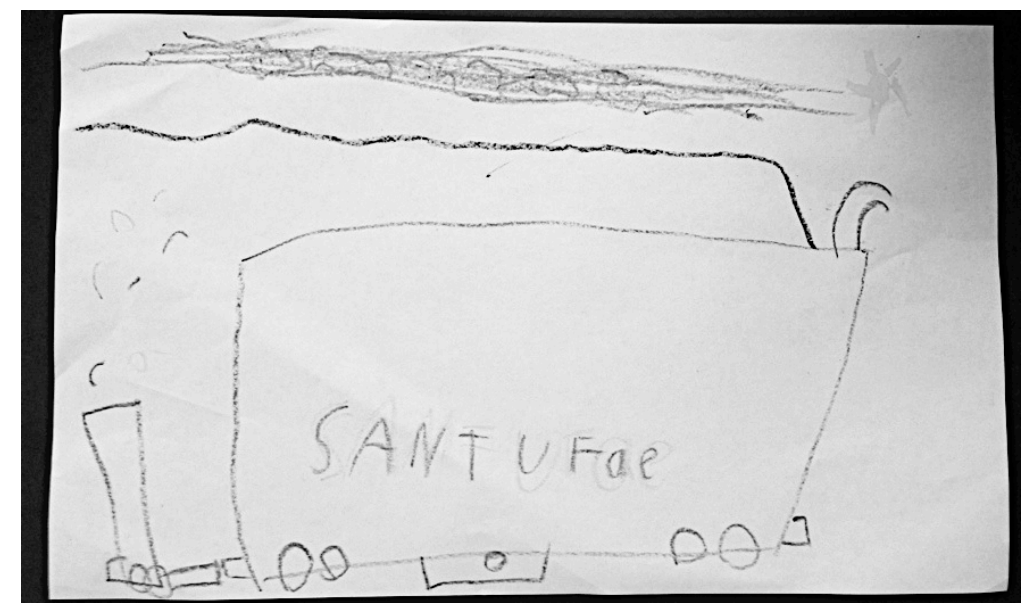

Figure 4. Brett's drawing of a train and "party car."

When I asked him why he drew a train, he said, "It was the first thing I think of... trains are fun... I like trains... Church is fun" (focus group interviews, 01/12/2014).

The children associated fun with the unstructured free play times that came immediately following being dropped off or before being picked up. In these times the children were allowed to freely choose various activities, games, and toys to play with. While the churches (leaders and curriculum) and the children constructed church as a place to have fun, the two groups constructed the role of fun differently. Rather than fun being a means to an end like it was for the adult church leaders, fun for the children was it's own aspect of church. Fun wasn't necessarily a direct part of the learning.

When it came to constructing church as a place to learn religious beliefs and values, church leaders and children had similar views. Both the adult leaders and children referred to learning Bible stories, Bible lessons, and Bible verses as how to learn about God. Two of the children's explanations of their drawings of church were indicative of how the children talked about the church as a place to learn. Darcy drew a 
picture of a Bible (Figure 5) because, in her words, "It's what we learn at church" (focus group interview, 01/05/2014).

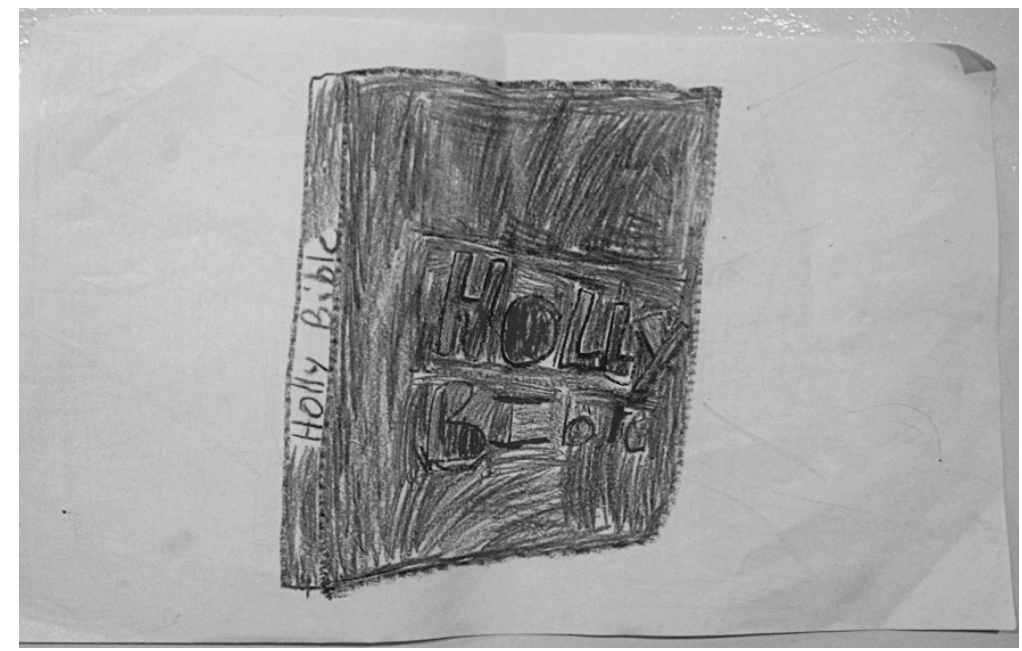

Figure 5. Carly's drawing of the Bible.

On a similar note, Michelle (age 6) drew a picture of a classroom full of tables and chairs (Figure 6) saying, "It's the small group room where we review what we learn" (focus group interview, 01/12/2014).

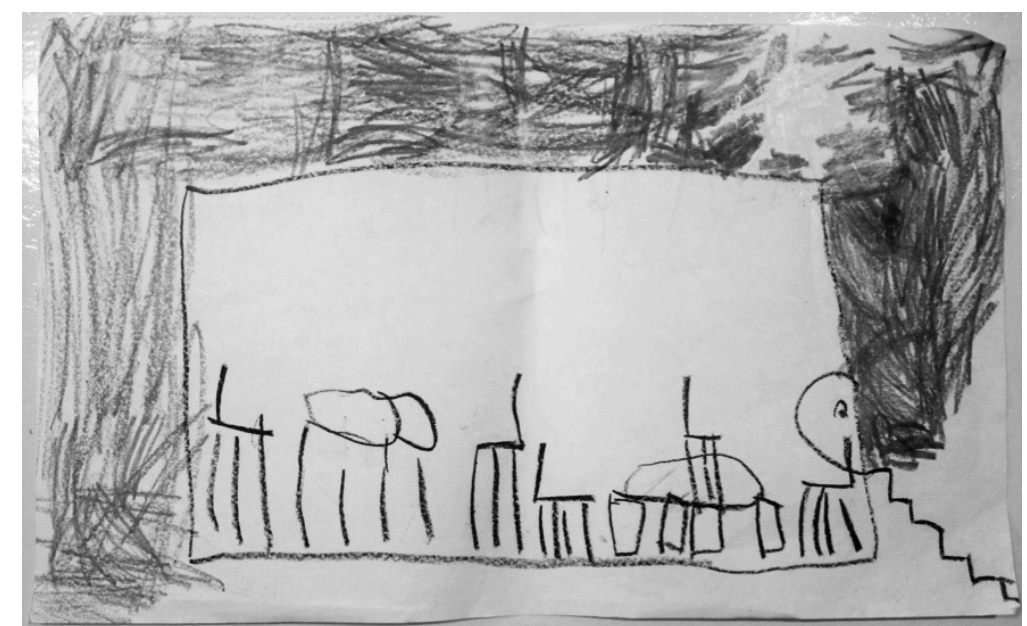

Figure 6. Landry's drawing of a small group room with tables and chairs.

Rather than constructing the church as a place where learning is dependent on fun as a pedagogical tool, the children linked fun and learning in such a way that the two aspects 
of church were interdependent. Just like Peter stated above, church was a place to "have fun about Jesus.”

Fun and learning: A symbiotic relationship. As I further analyzed data from the focus group interviews looking for how the children related to their churches as a place of fun and learning, it became apparent that fun and learning were symbiotically intertwined. Children consistently cited "fun" or "play" alongside learning about God or Jesus when asked about why they go to church, why it's important to go to church or why other people should go to church. Reflecting Peter's sentiments, which serve as the title of this chapter, Landon who was part of a different focus group simply stated that church is where "You play and learn" (focus group interview, 01/12/2014).

To further illustrate the connection between fun and learning in the children's relationships with their churches, Victor had been sharing extensively about how fun church was when he was dropped off and immediately before he was picked up because it was, in his words, "free time." In his description of the teaching time, however, he mentioned how boring it was because "you have to sit still and watch the whole time" (focus group interview, 01/12/2014). In a conversation with Victor's mother subsequent to the focus group interview, she stated that she was open to bringing Victor to the adult service with her if he expressed an interest in doing so (field notes, 01/12/2014). Yet, during the focus group interview I had asked Victor why he chose to continue coming to the children's programming, and he answered, "Because you learn about Jesus there" (focus group interview, 01/12/2014). Even though, in his opinion, the teaching methods were "boring," he still maintained a relationship with kid church because it was a place 
he could have fun in the form of "free time," and it was a place he learned about Jesus even though the learning wasn't fun. Since both fun and learning were present in some way, Victor remained committed to kid church.

Alternatively, I found that if either fun or learning was absent from kid church, then it seemed that the children were more likely to sever their relationship with kid church as was the case with Leroy when he expressed a desire to attend adult church over kid church even though he thought kid church was fun (focus group interview, 01/12/2014). While Leroy stated that he would rather be in the adult church to receive what he states as "deeper learning," there is not enough data to determine what the nature or extent of his commitment to the adult church would be. Regardless, when Leroy no longer believed he was learning at kid church, he was ready to switch congregations and attend adult church. In the final chapter, I will discuss some conclusions based on this study as well as some avenues for further research exploring children's participation in their religious communities. 


\section{Conclusion}

My journey leading to the research contained in this thesis began with a child who challenged my assumption of the meaning of "fun." Much like the emperor in The Emperor's New Clothes who realized that he was naked because the regal robes he believed he was wearing were non-existent, I was made aware of the habitus informing my suppositions of children and how they related to their churches. I assumed I knew how children related to church based on "common sense" and a priori knowledge. Over the course of this thesis, I have exposed not just my habitus but also that of others who work in children's religious education. Further, this research addresses a gap in the sociological literature regarding how children talk about their relationships to their church communities. In this chapter, I will, first, discuss the implications this research has for how one interprets and approaches current and future studies investigating how children relate to their religious communities. Second, I will discuss how this research might affect studies exploring how one's relationship with the church evolves through childhood into adolescence and into adulthood. Third, I will discuss the scope and limitations of this research. Lastly, I will offer suggestions for further research.

Studies on religious belonging, while not explicit, assume that children's relationships to their churches are tied to relationships children have with their parents and/or other adult congregants. Robinson (1983), Wuthnow (1999), and Hyde (1990), in their studies of children growing up religious, contain stories of people who link their childhood church experiences with their parents' involvement in church. Similarly, studies of church adherence (Dudley, 1999; Hoge \& Petrillo, 1978; Lopez et al., 2011; 
Smith \& Lundquist, 2005; Smith et al., 2002) base their analysis on adult recollections of people who connected with significant adult mentors as children in church. Since no explicit mention is made to the contrary by the literature on children's religious socialization, scholarship up to this point apparently assumes that when children talk about church or when people reflect on their memories of church as a child, they are referring to the same church their parents and/or other adults attended. In this thesis, I have challenged this assumption. I contend that children relate to the church as two separate "churches." Specifically, children approach the churches they attend as made up of two congregations: kid churches and adult churches. As a result of this bifurcated view of churches, children identify themselves as members of kid church. This can be seen in how the children in this study spontaneously compared "mom and dad church" and "church for the adults" to "my church" or "our church" when talking about "kid church" (focus group interviews, 01/05/2014, 01/12/2014).

As part of kid church, children have shared rituals that mark and reinforce children's membership in in kid church. Although Wuthnow (1999) contends that church-wide rituals serve as a way for children to form strong connections with the entire church, there is no discussion or recognition of rituals that are specific to children's experiences of church. In my discussion of the data, I have shown that rituals connected to kid church strengthen children's membership with kid church, suggesting children's alienation from the whole church. Consequently, this suggests that when children graduate from kid church, they may have little or no connections to the adult religious community. Longitudinal studies including children's voices before, during and after 
their transitions from kid church to adult church might shed light on how children negotiate their relationships with church into adulthood. Next, I will discuss the implications this research has for studies exploring religious adherence from childhood into adulthood.

As shown in the previous chapter, analysis of the data from focus group interviews showed that the children related to their churches as places to learn and have fun. This suggests that children's connection with kid church is dependent on children having fun and learning about God. This is not the same as "having fun learning about God." When children's sense of religious belonging is studied using this framework, my findings imply that children no longer have a sense of connection to "kid church" when they no longer have fun or they no longer feel like they are learning. As a result, the data suggests that children might choose to attend adult church. However, there is not sufficient data to determine if children who attend adult church evaluate their relationship with adult church in similar ways as they do for kid church. Will children still evaluate whether they were having fun and learning about God? Will they evaluate their connection to church on the basis of their parents' membership to the church? Will children appropriate a new set of rituals from adult church? Further research would be needed to explore these questions.

\section{Scope and Limitations of this Thesis}

While this study is an inductive exploration of only two evangelical Protestant churches in Northern California and the experiences of only eleven children, thereby potentially limiting the generalizability of the results and observations in this thesis, I 
have worked to connect the observations and data from this study with other studies of childhood (Corsaro, 2003, 2005; Corsaro \& Eder, 1990; Thorne, 1993) and religion in childhood (Bales, 2005; Beste, 2011; Boyatzis, 2011; Ridgely, 2011). Additionally, the churches in this study have been used by other Protestant churches across the United States as models for how to conduct various ministries, including children's ministry. Finally, drawing from Peek and Fothergill (2009), I believe that the small number of children interviewed in focus groups provided sufficient data for the analysis in this thesis.

\section{Suggestions for Further Study}

Future studies exploring children's constructions of their relationship to the church should include more churches with a variety of approaches to children's ministry to broaden the scope and generalizability of the findings in this study. Another avenue of research could employ an institutional ethnography approach exploring what Smith (2005) refers to as the ruling relations between the church and kids and how the church exerts power over the lives of children through the institutional discourse found within the church's various texts. Lastly, as a way to broaden the study of children in religion, it is important to examine how children of other faiths relate to their religious communities. 


\section{References}

Babbie, E. (2013). The practice of social research (13th ed.). Belmont, CA: Wadsworth.

Bales, S. R. (2005). When I was a child: Children's interpretations of first communion. Chapel Hill, NC: The University of North Carolina Press.

Beste, J. (2011). Children speak: Catholic second graders' agency and experiences in the sacrament of reconciliation. Sociology of Religion, 72, 327-350.

Blanchet-Cohen, N., \& Rainbow, B. (2006). Partnership between children and adults? The experience of the International Children's Conference on the Environment. Childhood, 13,113-126.

Boyatzis, C. (2011). Agency, voice, and maturity in children's religious and spiritual development. In S. B. Ridgely (Ed.), The study of children in religions (pp. 19-32). New York, NY: New York University.

Carrier, H. (1965). The sociology of religious belonging. (A. J. Arrieri, Trans.). New York, NY: Herder \& Herder.

Charmaz, K. (2006). Constructing grounded theory: A practical guide through qualitative analysis. Thousand Oaks, CA: SAGE Publications.

Cheney, K. E. (2011). Children as ethnographers: Reflections on the importance of participatory research in assessing orphans' needs. Childhood, 18, 166-179.

Clark, C. D. (2011). Navigating the institutional review board (IRB) for child-directed qualitative research. In S. B. Ridgely (Ed.), The study of children in religions, (pp. 67-79). New York, NY: New York University.

Coles, R. (1990). The spiritual life of children. Boston, MA: Houghton Mifflin Company.

Carter, J. S., \& Corra, M. (2005). Changing attitudes toward women, 1972-1998: The liberalization of religious fundamentalism. Michigan Sociological Review, 19, 1944.

Casanova, J. (2003). Beyond European and American exceptionalisms: Towards a global perspective. In G. Davie, P. Heelas, \& L. Woodhead (Eds.), Predicting religion: Christian, secular, and alternative futures (pp. 17-29). Burlington, VT: Ashgate Publishing Company. 
Cheney, Kristen E. "Children as Ethnographers: Reflections on the Importance of Participatory Research in Assessing Orphans' Needs." Childhood 18(2):166179.

Corsaro, W. A. (2003). We're friends, right?: Inside kids' culture. Washington, D.C.: Joseph Henry Press.

Corsaro, W. A. (2005). The sociology of childhood, second edition. Thousand Oaks, CA: Pine Forge Press.

Corsaro, W. A., \& Eder, D. (1990). Children's peer cultures. Annual Review of Sociology, $16,197-220$.

de Castro, L. R. (2012). The "good-enough society", the "good-enough citizen" and the "good-enough student": Where is children's participation agenda moving to in Brazil? Childhood, 19, 52-68.

Darbyshire, P., MacDougal, C., \& Schiller, W. (2005). Multiple methods in qualitative research with children: More insight or just more. Qualitative Research, 5, 417436.

Dillen, A. (2007). Religious participation of children as active subjects: Toward a hermeneutical-communicative model of religious education in families with young children. International Journal of Children's Spirituality, 12, 37-49.

DiMaggio, P., Evans, J., \& Bryson, B. (1996). Have Americans' social attitudes become more polarized?" American Journal of Sociology, 102, 690-755.

Dudley, R. (1999). Youth religious commitment over time: A longitudinal study of retention. Review of Religious Research, 41, 110-121.

Durkheim, E. (1915). The elementary forms of the religious life. (J. W. Swain, Trans.). London, United Kingdom: George Allen \& Unwin Ltd. (Original work published 1912)

Fowler, J. (1981). Stages of faith: The psychology of human development and the quest for meaning. New York, NY: HarperCollins Publishers.

Gallagher, S. K. (2004). The marginalization of evangelical feminism. Sociology of Religion, 65, 215-237.

Gallagher, S. K. (2007). Children as religious resources: The role of children in the social re-formation of class, culture, and religious identity. Journal for the Scientific Study of Religion, 46, 169-183. 
Graham, A., \& Fitzgerald, R. (2010). Progressing children's participation: Exploring the potential of a dialogical turn. Childhood, 17, 343-359.

Greeley, A. M. (1972). The denominational society: A sociological approach to religion in America. Glenview, IL: Scott, Foresman, and Company.

Gunnoe, M. L., \& Moore, K. A. (2002). Predictors of religiosity among youth aged 1722: A longitudinal study of the National Survey of Children. Journal for the Scientific Study of Religion, 41, 613-622.

Harms, E. (1944). The development of religious experience in children. American Journal of Sociology, 50, 112-122.

Hoffman, J. P., \& Bartowski, J. P. (2008). Gender, religious tradition, and biblical literalism. Social Forces, 86, 1245-1272.

Hoge, D. R., \& Petrillo, G. H. (1978). Determinants of church participation and attitudes among high school youth. Journal for the Scientific Study of Religion, 17, 359379 .

Hunter, J. D. (1991). Culture wars: The struggle to define America. New York, NY: Basic Books.

Hyde, K. (1990). Religion in childhood and adolescence. Birmingham, AL: Religious Education Press, Inc.

Jans, M. (2004). Children as citizens: Towards a contemporary notion of child participation. Childhood, 11, 27-44.

Leech, B. (2002). Asking questions: Techniques for semi-structured interviews. Political Science \& Politics, 35, 665-668.

Leege, D. C. (1993). Religion and politics in theoretical perspective. In D. C. Leege and L. A. Kellstedt (Eds.), Rediscovering the religious factor in American politics (pp. 3-25). Armonk, NY: M. E. Sharpe.

Lenski, Gerhard. (1961). The religious factor: A sociological study of religion's impact on politics, economics, and family life. Garden City, NY: Doubleday \& Company, Inc.

Lopez, A. B., Huynh V. W., \& Fuligni, A. J. (2011). A longitudinal study of religious identity and participation during adolescence. Child Development, 82, 1297-1309. 
Mannion, G., \& I'anson, J. (2004). Beyond the Disneyesque: Children's participation, spatiality and adult-child relations. Childhood, 11, 303-318.

Manza, J., \& Brook, C. 1997. The religious factor in U.S. presidential elections, 19601992. American Journal of Sociology, 103, 38-81

Marx, K. (1970). Critique of Hegel's philosophy of right. (A. Jolin and J. O'Malley, Trans.). New York, NY: Cambridge University Press. (Original work published 1843)

McConkey, D. (2001). Whither Hunter's culture war? Shifts in evangelical morality, 1988-1998. Sociology of Religion, 62, 149-174.

Miller, S., \& Staal, D. (2004). Making children's ministry the best hour of every kids' week. Grand Rapids, MI: Zondervan.

Montell, F. (1999). Focus group interviews: A new feminist method. NWSA Journal, 11, 44-71.

Morgan, M., Gibbs, S., Maxwell, K., \& Britten, N. (2002). Hearing children's voices: Methodological issues in conducting focus groups with children aged 7-11 years. Qualitative Research, 2, 5-20.

Mullender, A. (2006). What children tell us: "He said he was going to kill our mum." In C. Humphreys and N. Stanley (Eds.), Domestic violence in the lives of children: The future of research, intervention, and social policy (pp. 53-68). Philadelphia, PA: Jessica Kingsley Publishers.

Peek, L., \& Fothergill, A. (2009). Using focus groups: Lessons from studying daycare centers, 9/11, and Hurricane Katrina. Qualitative Research, 9, 31-59.

Powell, K. E., \& Clark, C. (2011). Sticky faith: Everyday ideas to build lasting faith in your kids. Grand Rapids, MI: Zondervan.

Qvortrup, J. (1994). “Childhood matters: An introduction.” In J. Qvortrup, M. Bardy, G. Sgritta, and H. Wintersberger (Eds.), Childhood matters: social theory, practice and politics (pp. 1-24). Aldershot, UK: Avebury.

Reinharz, S. (1992). Feminist methods in social research. New York, NY: Oxford University Press.

Ridgely, S. B. (2011). “Maybe the picture will tell you”: Methods for hearing children's perspectives on religion. In S. B. Ridgely (Ed.), The study of children in religions (pp. 80-94). New York, NY: New York University. 
Ridgely, S. B. (2012). Doing ethnography with child consultants: Making the IRB process work. Journal of American Folklore, 125, 474-485.

Robinson, E. (1983). The original vision: A study of the religious experience of childhood. New York, NY: The Seabury Press.

Shanahan, S. (2007). Lost and found: The sociological ambivalence toward childhood. Annual Review of Sociology, 33, 407-428.

Sherkat, D. E. (2000). "That they be keeper of the home": The effects of conservative religion on early and late transitions into housewifery. Review of Religious Research, 41, 344-358.

Sherkat, D., \& Ellison, C. (1999). Recent developments and current controversies in the sociology of religion. Annual Review of Sociology, 25, 363-394.

Silverman, D. (2010). Doing qualitative research: A practical handbook (3rd ed.). Los Angeles, CA: SAGE Publications.

Smith, C., \& Lundquist, M. (2005). Soul searching: The religious and spiritual lives of American teenagers. New York, NY: Oxford University Press.

Smith, C., Denton, M. L., Faris, R., \& Regnerus, M. (2002). Mapping American adolescent religious participation. Journal for the Scientific Study of Religion, 41, 597-612.

Smith, D. E. (2005). Institutional ethnography: A sociology for people. New York, NY: Altamira Press.

Stark, R., \& Bainbridge, W. S. (1996). A theory of religion. New Brunswick, NJ: Rutgers University Press. (Original work published 1987)

Thomas, J. N., \& Olson, D. V. (2012). Evangelical elites' changing response to homosexuality 1960-2009. Sociology of Religion, 73, 239-272.

Thomas, N. (2007). Towards a theory of children's participation. International Journal of Children's Rights, 15, 199-218.

Thorne, B. (1993). Gender play: Girls and boys in school. New Brunswick, New Jersey: Rutgers University Press. 
Waksler, F. (1991). Studying children: Phenomenological insights. In F. Waksler (Ed.), Studying the social worlds of children: Sociological readings, (pp. 60-70). New York, NY: Falmer.

Wald, K. D. (1992). Religion and politics in the United States (2nd ed.). Washington, D.C.: Congressional Quarterly Inc.

Wald, K. D., Owen, D., \& Hill, S. 1988. Churches as Political Communities. The American Political Science Review, 82, 531-48

Weber, M. (2012). The Protestant ethic and the spirit of capitalism (Amazon Kindle eBook ed.). (T. Parsons, Trans.). New York, NY: Start Publishing, LLC. (Original work published 1930)

White, R. (1968). Towards a theory of religious influence. Pacific Sociological Review, 11, 23-28.

Whyte, W. F. (1979). On making the most of participant observation. The American Sociologist, 14, 56-66.

Wilcox, W. B., Chaves, M., \& Franz, D. (2004). Focused on the family? Religious traditions, family discourse, and pastoral practice. Journal for the Scientific Study of Religion, 43, 491-504.

Wuthnow, R. (1976). Recent pattern of secularization: A problem of generations? American Sociological Review, 41, 850-867.

Wuthnow, R. (1985). The growth of religious reform movements. Annals of the American Academy of Political and Social Science, 480, 106-116.

Wuthnow, R. (1999). Growing up religious: Christians \& Jews \& their journeys of faith. Boston, MA: Beacon Press.

Zelizer, V. (1994). Pricing the priceless child: Determining the social value of children. Princeton, NJ: Princeton University Press.

Zinn, M. B. (1979). Field research in minority communities: Ethical, methodological and political observations by an insider. Social Problems, 27, 209-219.

Zonio, H. (2013, March/April). Kids' lowdown on high tech. Children's Ministry Magazine, 23(1), 54-57. 


\section{Appendix A}

\section{IRB Approval Letter}

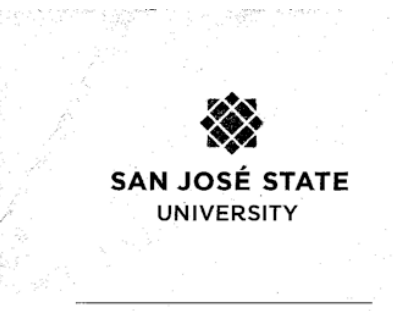

Division of Academic Affairs

Associate Vice President Graduate Studies \& Research

www.sjsu.edu/gradstudies

One Washington Square San José, California 95192-0025 Voice: $408-924-2.427$

Fax: 408-924-2612

www.sjsu.edu

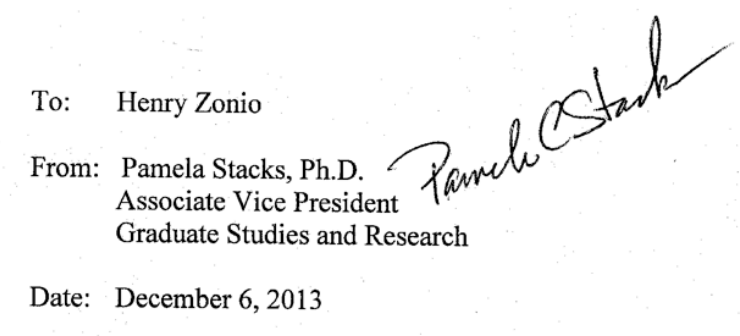

The Human Subjects-Institutional Review Board has approved your request to use human subjects in the study entitled:

"Children's Construction of their Relationships to the Church"

This approval is contingent upon the subjects participating in your research project being appropriately protected from risk. This includes the protection of the confidentiality of the subjects' identity when they participate in your research project, and with regard to all data that may be collected from the subjects. The approval includes continued monitoring of your research by the Board to assure that the subjects are being adequately and properly protected from such risks. If at any time a subject becomes injured or complains of injury, you must notify Dr. Pamela Stacks, Ph.D. immediately. Injury includes but is not limited to bodily harm, psychological trauma, and release of potentially damaging personal information. This approval for the human subject's portion of your project is in effect for one year, and data collection beyond December 6, 2014 requires an extension request.

Please also be advised that all subjects need to be fully informed and aware that their participation in your research project is voluntary, and that he or she may withdraw from the project at any time. Further, a subject's participation, refusal to participate, or withdrawal will not affect any services that the subject is receiving or will receive at the institution in which the research is being conducted.

If you have any questions, please contact me at.(408) 924-2427.

Protocol \# S1304099

cc. Susan Murray $\quad 0122$ 


\section{Appendix B}

\section{Informed Consent Letter for Parents}

Parent/Guardian Agreement for Child/Ward to Participate in Research

"Children's Constructions of Their Relationships to the Church"

(Responsible Investigator: Henry Zonio, SJSU Graduate Student)
SAN JOSÉ STAT
UNIVERSITY

Please read carefully the following information.

College of Social Sciences

Department of Sociology and Interdisciplinary Social Sciences

One Washington Square San José, California 95192-0122 Phone: (408) 924-5320 Fax: (408) 924-5322 sociology@sjsu.edu

www.sjsu.edu
1. Your child or ward has been asked to participate in a research study investigating how children talk about and understand their relationship to their church.

2. Your child or ward will be asked to participate in a group interview made up of children from the church you attend. Your child will be asked open-ended questions about their church-related experiences. Your child may also be asked to draw about their churchrelated experiences. The group interview will take place onsite at the church you attend.

3. There is no anticipated risk to you or your child or ward from participating in this project.

4. There is no anticipated direct benefit to you or your child or ward from participating in this project other than the extent to which you or your child or ward value contributing your knowledge and expertise to research and informed decision making.

5. Although the results of this study may be published, no information that could identify your child or ward, your family, or you will be included.

6. You may be asked if the interview can be recorded with an audio and/or video recorder. You have the right to refuse to allow the interview to be recorded before or at any point during the interview.

7. You will not be compensated in any way for your participation in this project.

8. Questions about this research may be addressed to Henry Zonio (henry.zonio@sjsus.edu). Complaints about the research may be presented to Wendy $\mathrm{Ng}$, Chair, Department of Sociology, (408)924-5594. Questions about a research participant's rights, or researchrelated injury may be presented to Pamela Stacks, Ph.D., Associate Vice President, Graduate Studies and Research, at (408)924-2427.

9. No service of any kind, to which you and/or your child or ward is otherwise entitled, wil be lost or jeopardized if you choose not to participate in the study.

10. Your consent for your child or ward to participate is being given voluntarily. You may refuse to allow his or her participation in the entire study or in any part of the study. You child/ward has the right to not answer questions that he/she does not wish to answer. If you allow his or her participation, you are free to withdraw your child or ward from the study at any time without any negative effect on your relations with San Jose State or [Name of church where group interview is taking place]. Your child also has the right to withdraw from this study at any time. 
At the time that you sign this consent form, you will receive a copy of it for your records, signed and dated by the investigator.

SAN JOSÉ STATE

UNIVERSITY

College of Social Sciences

Department of Sociology and Interdisciplinary Social Sciences

One Washington Square

San José, California 95192-0122

Phone: (408) $924-5320$

Fax: (408) $924-5322$

sociology@sjsu.edu

www.sjsu.edu
- The signature of a parent or legal guardian on this document indicates:

- approval for the child or ward to participate in the study,

$\circ$ that the child is freely willing to participate, and

- that the child is permitted to decline to participate, in all or part of the study, at any point.

- The signature of a researcher on this document indicates agreement to include the above named participant in the research and attestation that the participant's parent or guardian has been fully informed of the participant's rights.

Name of Child

Parent or Guardian Signature

Date

Relationship to Child or Ward

Full Mailing Address (optional)

Investigator's Signature

Date 


\title{
Appendix C
}

\section{Informed Consent Letter for Children}

\author{
Agreement to Participate in Research \\ "Children's Constructions of Their Relationships to the Church" \\ (Responsible Investigator: Henry Zonio, SJSU Graduate Student)
}

SAN JOSÉ STATE

UNIVERSITY

Parents or Guardians, please carefully review this with your children.

1. You've been asked to help people know what kids say about going to church and being part of a church.

College of Social Sciences

2. If you agree to be a part of this, you'll be asked to hang out at church with some other kids around your age on a Sunday after church is over. A student from San Jose State University, Henry, wants to know what you and other kids have to say about going to church and being part of a church. He'll ask some questions, and you'll get to help him

Department of Sociology and Interdisciplinary Social Sciences

One Washington Square San José, California 95192-0122

Phone: (408) 924-5320

Fax: (408) 924-5322

sociology@sjsu.edu

www.sjsu.ed understand what kids like you think. It'll all take about an hour.

3. You won't be asked to do anything dangerous.

4. You aren't being paid to be a part of the project, but you will be helping people understand better what kids think about going to church.

5. Henry will ask you if it's OK to record the time you and the other kids are talking about church. The only reason for the video is to help Henry remember what you all talk about during your time together with him and the other kids that will be in the group. The video won't be shown to anyone without your permission. If you don't want video to be recorded, just let Henry know.

6. Even though Henry is writing a report using what he learns from you, no one will know you were a part of the project.

7. If you have any questions about this project, your parents know how to get a hold of Henry. You will also be able to ask Henry any questions before you and the other kids start talking about what you think of going to church.

8. You can choose to stop being part of the project at any time before, during, or after the time you spend with Henry and the other kids.

9. It's up to you to be a part of this project. If you change your mind at any time and don't want to participate anymore, that is OK. Also, you don't have to answer any of the questions you don't want to.

If you want to be a part of this project helping people know what kids have to say about going to church and being part of church, check the box and write or sign your name on the line that says "Participant's Signature."

\section{YES, I want to be a part of this project.}

Participant's Name (written by participant)

Date

The signature of a researcher on this document indicates agreement to include the above named participant in the research and attestation that the participant has been fully informed of his or her rights. 